\begin{tabular}{|l|l|l|l|l|l|}
\hline MUNIBE Antropologia-Arkeologia & $\mathrm{n}^{\circ} 65$ & $289-312$ & DONOSTIA & 2014 & ISSN 1132-2217 • eISSN 2172-4555 \\
\hline
\end{tabular}

\title{
Placas de identificación de combatientes de la Guerra Civil española (1936-1937), recuperadas en exhumaciones de escenarios bélicos en el País Vasco
}

\author{
Identification discs of soldiers in the Spanish Civil War (1936-1937), \\ recovered in exhumations of war scenarios in the Basque Country
}

\begin{abstract}
KEY WORDS: Identification discs (Dog Tags), Mass graves, Spanish Civil War, Forensic Anthropology.
PALABRAS CLAVES: Placas de identificación, Fosas comunes, Guerra Civil, Antropología Forense.

GAKO-HITZAK: Identifikazio-plakak, Hilobi komunak, Gerra Zibila, Auzitegiko Antropologia.
\end{abstract}

\section{Lourdes HERRASTI(1), Alberto J. SAMPEDRO(2), Joseba DIÉGUEZ(3), Jon ETXEZARRAGA(4), AIfredo IRUSTA(5), Jimi JIMÉNEZ(6), Iñaki REBOLLEDO(7), Alberto SARDÓN(8), Eduardo SARDÓN( ${ }^{(9)}$ y Francisco ETXEBERRIA ${ }^{(10)}$}

\section{ABSTRACT}

At the end of the 19th century, concern about the identity of soldiers injured or killed in battle motivated the creation of an identification system with metal discs that hung from the neck or were worn around the wrist. It was the soldiers themselves who were afraid of dying without an identity.

Personal identification plates have had a long tradition in all armies, although their use spread in the 20th century as a result of the First World War. Their use is currently regulated by specific provisions that follow the same original idea.

The implementation of the systematic exhumation of soldiers' mass-graves by professional archaeologists has allowed the recovery of some of these objects, which are of great importance to ascertain the historical facts and permit an identification of the cases, which is very useful from a forensic perspective.

The use of these discs meant that the bodies in the battlefield could be identified and also that the fact could be recorded in a reliable way. These same discs are currently used to establish the identity of individuals recovered in exhumations of human remains from the Spanish Civil War (19361939). These exhumations have been performed according to scientific method.

We present several examples of identification discs which have been recovered in these exhumations, and which have facilitated the identification of the soldiers buried in them

\section{RESUMEN}

A finales del s. XIX la preocupación por conocer la identidad de los soldados heridos o fallecidos en una batalla motivó la creación de un sistema de identificación con placas metálicas que se llevaban suspendidas del cuello o alrededor de la muñeca. Los propios soldados sentían temor de no ser identificados tras su muerte.

Las placas de identificación personal cuentan con una larga tradición en todos los ejércitos, si bien su uso se generaliza en el siglo XX como consecuencia de la Primera Guerra Mundial. Su aplicación sigue vigente y se encuentra regulada en la actualidad por disposiciones concretas que mantienen la misma idea suscitada en su origen.

El uso de estas placas permitía conocer la identidad de los cadáveres en el mismo lugar de la contienda, tanto para los heridos como para los muertos, y registrar el hecho documentalmente de forma fehaciente. En la actualidad, estas mismas placas, han servido para establecer las identidades de los restos humanos recuperados en las exhumaciones de la Guerra Civil (1936-1939), que se han realizado siguiendo una metodología científica.

La puesta en marcha de exhumaciones sistemáticas con presencia de arqueólogos profesionales ha posibilitado la recuperación de algunas de estas evidencias que son de gran importancia para constatar los hechos históricos y posibilitar una orientación identificativa de los casos que es gran ayuda desde la perspectiva forense.

Se presentan varios ejemplos en los que las placas de identificación, recuperadas en las exhumaciones realizadas en el País Vasco, han facilitado determinar la identidad de los soldados allí enterrados.

\footnotetext{
(1) Departamento de Antropología Sociedad de Ciencias Aranzadi. Donostia-San Sebastián. antropología@aranzadi-zientziak.org

(2) Sociedad de Ciencias Aranzadi. Donostia-San Sebastián. alberto.ixile@gmail.com

(3) Sociedad de Ciencias Aranzadi. Donostia-San Sebastián. njoseba@yahoo.es

(4) Sociedad de Ciencias Aranzadi. Donostia-San Sebastián. jonetxezarraga@gmail.com

(5) Sociedad de Ciencias Aranzadi. Donostia-San Sebastián. barbadun68@yahoo.es

(6) Departamento de Antropología Sociedad de Ciencias Aranzadi. Donostia-San Sebastián. jimix77@hotmail.com

(7) Sociedad de Ciencias Aranzadi. Donostia-San Sebastián. tostarteko@yahoo.com

(8) Sociedad de Ciencias Aranzadi. Donostia-San Sebastián. albertosardon@terra.es

(9) Sociedad de Ciencias Aranzadi. Donostia-San Sebastián. eduardosardon@yahoo.com

(10) Medicina Legal y Forense. Facultad de Medicina. Universidad del País Vasco UPV/EHU. Apartado 1599. 20014 Donostia - San Sebastián. paco.etxeberria@ehu.es
} 


\section{LABURPENA}

XIX. mende bukaeran gatazka batean zauritutako edota hildako soldaduen identitatea ezagutzeko kezkak identifikazio-sistema sortzea ekarri zuen, lepotik behera edota eskumuturraren inguruan zintzilik eramateko plaka metalikoak, hain zuzen ere. Soldadu beraiek beldur ziren identifikatu gabe hiltzea.

Armada guztietan pertsonak identifikatzeko plakek tradizio handia dute, zehazki XX. mendean haien aplikazioa zabaldu zen Lehen Mundu Gerraren ondorioz. Gaur egun, plaken erabilera zehatzak diren xedapenekin arauturik dago, oraindik ere jatorrizko funtzioa mantentzen dutelarik.

Gatazka bera gertatu zen lekuan, plaka edo disko hauen erabilpenari esker, hildakoen identitatea ezagutzea ahalbidetu zen eta heriotza hor behar moduan jasota geratzea. Egun, plaka horiek metodo zientifikoen bidez, Gerra Zibileko (1936-1939) deshobiraketetan errekuperaturiko giza gorpuzkinen identitatea ezagutzeko ere balio izan dute.

Arkeologo profesionalen eskutik bideraturiko deshobiraketa sistematikoak abian jartzeak gertaera historikoak egiaztatzen dituzten hainbat ebidentzia eskuratzea erdietsi da, eta, baita ere, auzitegiko ikuspuntutik, identifikaziorako lagungarria den bidea ematea.

Jarraian honi buruzko adibide batzuk aurkezten dira, non deshobiraketetan eskuratu diren identifikazio-plakek bertan lurperaturik zeuden soldaduen identitatea argitu duten.

\section{1.- INTRODUCCIÓN}

La existencia de placas de identificación se inició por la necesidad que los soldados tenían de ser identificados si eran evacuados heridos durante la batalla o ante la eventualidad de su muerte. Por la tanto, originariamente la iniciativa partió de los propios combatientes que guardaban una nota de papel con su nombre y dirección en el interior del bolsillo o guardado en la mochila de su espalda.

Los soldados no querían morir en el anonimato o terminar en una fosa común sin ninguna referencia nominal. Por ello, se procuraron placas de madera para ser colgadas en el cuello, o recurrieron a los brazaletes o a discos de metal para que fueran engarzados en pulseras.

Ya en época griega los esclavos llevaban tatuado su nombre y en épocas posteriores los guerreros se identificaban mediante la armadura, el arma, un emblema o cualquier signo externo que permitiera ser reconocidos en caso de caer en combate. Sin embargo, el inicio del uso generalizado de la placa militar se sitúa en la Guerra de Secesión de los Estados Unidos de América. Cada soldado llevaba una pequeña placa con el nombre del portador "I am...", además del nombre de la Compañía, Regimiento, División y ejército al que pertenecía. Los combatientes no deseaban convertirse en soldados desconocidos desaparecidos en combate.

Estas placas de identificación tienen, asimismo, un valor arqueológico pues forman parte de los objetos asociados que pueden recuperarse en una exhumación de soldados. A ello se añade su utilidad en los procesos de identificación forense, que se llevan a cabo en cooperación con otras técnicas especializadas.

\section{a) Objetivo y función de las placas de identificación}

Se trataba de permitir la identificación del soldado, que no solo era válida en los casos de fallecimiento, sino también en el de los heridos que habían perdido el conocimiento, en los casos de amnesias parciales o totales y también para impedir suplantaciones o falsificaciones

De esa manera si un soldado moría, un compañero podía recuperar una de las placas o la mitad de la misma, si era doble, con el fin de dar a conocer su fallecimiento y, al mismo tiempo, el cadáver mantenía la otra mitad o la otra placa para poder ser identificado en su inhumación o en su posterior exhumación con independencia del tiempo trascurrido.

\section{b) Material de las placas}

La placas debían están fabricadas en metal ligero resistente a la corrosión. Por esa razón, el aluminio utilizado en una primera fase fue sustituido más tarde por el zinc. En la actualidad se emplea el monel (aleación de níquel y cobre, en proporción de 2 a 1) o el acero inoxidable. Durante la Primera Guerra Mundial, en el Reino Unido se optó por el uso de fibra de asbesto vulcanizada que permitía suplir la escasez de metal para el volumen de placas que se precisaba.

\section{c) Forma de las placas}

Puede ser variada, pero predominan las formas circulares o las ovales. La placa, en algunos casos, está troquelada para fragmentarse en dos partes. Ambas mitades son iguales y normalmente la inscripción está dispuesta de forma simétrica. En algunos países se utilizan dos discos iguales que cuelgan de una cuerda, siendo una más corta que la otra.

\section{d) Fabricación de las placas}

De hecho, muchas veces los discos metálicos se grababan de manera improvisada en zonas próximas a la contienda. Para ello existían unas maletas que contenían los instrumentos necesarios para troquelar y grabar las placas, como son los puntales con las letras del alfabeto, un yunque de madera con el rebaje para apoyar el disco, y el martillo.

\section{e) Datos recogidos en las placas}

El volumen de datos estampados en las placas de identificación es variable, pero como mínimo se recogen: Número de identificación. Apellido y nombre completo o por siglas. $N^{\circ}$ división y batallón.

Y son opcionales: Fecha de nacimiento. Grupo sanguíneo. Religión. № Seguridad Social. Huella dactilar. Familiar más cercano.

Las referencias al número y regimiento son imprescindibles para la función de las placas de identificación. Sin 
embargo, el nombre completo o las siglas del mismo no están presentes en muchos de los modelos. Los datos considerados como secundarios son también importantes. Los médicos de guerra solicitaron se incorporara la reseña del grupo sanguíneo, para evitar la pérdida de tiempo en analizar la sangre y así realizar la transfusión con urgencia.

En el ejército naval americano se decidió la inclusión de una huella dactilar que quedara estampada en el reverso de la placa, para facilitar la identificación en caso de que la corrosión marina destruyera o desdibujara los datos del anverso de la placa.

Los números de placas, así como los datos de las personas correspondientes a las que habían sido asignadas se registraban en listados, donde se recogían también las incidencias de cada soldado como su desaparición o su baja por fallecimiento. Estos registros debían ser escrupulosos en la gestión del volumen de datos, por lo que tenían que ser asimismo actualizados periódicamente.

\section{BREVE HISTORIA DEL USO DE LAS PLACAS DE IDENTIFICACIÓN}

El uso generalizado de las placas de identificación se constata durante la Guerra civil de Secesión americana (1861-1865). En 1862, el representante John Kennedy propuso el uso de un Identity Disk (ID), pero fue rechazado. Sin embargo, muchos soldados que combatían en dicho conflicto se equiparon con una etiqueta de tela que cosían en su uniforme o un trozo de papel con su nombre, que guardaban en el bolsillo.

Pero también se difundió un tipo de placas que mostraban en el anverso un águila o escudo con lemas como "La guerra de la Unión" "Guerra de 1861" o también el perfil de George Washington o de McClellan. En el reverso se grababa el nombre del soldado y unidad a la que pertenecía. (MAIER y STAHL, 2008)

En 1864, durante la guerra germano-danesa, también en Prusia se produjo una propuesta similar que condujo a la creación de una placa que se denominó Hundemarken (etiquetas de perro).

La importante pérdida de vidas en el ejército prusiano en la batalla de Sadowa (1866) y la imposibilidad de identificar los cadáveres forzó a adoptar un sistema que sirviera para solventar ese problema. Así, en 1869, se estableció el uso de una placa metálica que se suspendía del cuello mediante una cuerda. En la guerra franco-prusiana iniciada en 1870 , se utilizaron las primeras placas oficiales o Reconogcircunsmarke (placa de reconocimiento).

Otros países fueron progresivamente adoptando esta medida. En 1881, en Francia y Bélgica; en 1902, Austria y Rusia; en 1907, en Gran Bretaña; en Italia, en 1915; y en Estados Unido, en 1916.

\section{Placas de la Primera Guerra Mundial}

Los países contendientes en la Primera Guerra Mundial implantaron, sino lo habían hecho antes, el uso de pla- cas personales de identificación para los millones de soldados que lucharon en la Gran Guerra (1914-1919).

Gran Bretaña: Durante el periodo de la Paz Armada se ideó un disco circular de 35 mm de diámetro de metal, normalmente de aluminio. Debía estar impreso con los datos del soldado que lo iba a portar: número, rango, nombre, regimiento y religión.

El inicio de la guerra en agosto de 1914, y la necesidad de disponer de un gran número de discos en un corto plazo obligó a cambiar el modelo. Se eligió un disco realizado en fibra de asbesto vulcanizado de color marrón-rojizo.

El sistema fue perfeccionado en 1916 (Orden 287 de septiembre de 1916), que reglamentó el uso de dos discos, uno de forma octogonal de fibra vulcanizada de color verde y un segundo disco circular de color rojo. El primer disco se colgaba del cuello mediante una cuerda; el segundo se ataba por debajo del anterior. De esta manera, el segundo disco podría ser arrancado y servía para notificar el fallecimiento del soldado, mientras que el primer disco quedaba junto o sobre el cadáver, lo que permitiría identificarlo en un futuro.

Sin embargo, la elección de este material ha supuesto un importante hándicap para la identificación de los soldados británicos exhumados en la actualidad. La fibra vulcanizada se ha deteriorado y resultan ilegibles los datos que en ellas estaban grabados. Esto ha podido suceder en la fosa de Arras, donde se hallaron inhumados 24 soldados del $10^{\circ}$ regimiento de Lincolnshire (Grimsby Chums), pero no se recuperó ningún disco de identificación.

Alemania: El nuevo disco, establecido en 1915, tenía forma oval de $7 \mathrm{~mm}$ de diámetro mayor y $5 \mathrm{~mm}$ de diámetro menor, realizado en aluminio. Los datos grabados correspondían al número del soldado, la fecha de nacimiento y los datos del regimiento. Para solventar el problema de que el cadáver no pudiera ser identificado si se le quitaba la placa, se planteó la solución de dividir el disco en dos mitades con la misma información, dispuesta de forma simétrica o especular, de manera que podría retirarse la mitad inferior, al tiempo que la mitad superior quedaba asociada al cuerpo del soldado.

Como quiera que las placas alemanas carecen del nombre o de las iniciales del soldado, era imprescindible que el servicio de documentación o la Wehrmacht guardara los registros de números y nombres para poder facilitar la consulta posterior. Cada unidad guardó su lista, y una copia era enviada diez meses después de la formación de la unidad a la Oficina de Información de las Fuerzas Armadas de Berlín. Esta lista debía ser actualizada cada mes.

Asimismo, se habilitaron estuches de cuero, de fabricación artesanal y particular, para proteger la placa de identificación y evitar el contacto frío del metal contra la piel.

Francia: Durante la guerra franco-prusiana (1870-71) los soldados franceses no disponían de placas identificativas y los cadáveres eran enterrados en fosas comunes. En septiembre de 1881 se incorporó una placa similar a la 
utilizada en Alemania, de forma oval de $3 \mathrm{~cm}$ de eje mayor y $2 \mathrm{~cm}$ de eje menor, realizada en aluminio.

En 1915, siguiendo las recomendaciones del doctor Leclerc, profesor de la facultad de Medicina de Lille, también se añadió una segunda placa idéntica a la primera, que podía ser llevada como pulsera por lo que la placa tenía un orificio a cada lado (CAPDEVILLA y VOLDMAN, 2002:754). Sin embargo, el sistema de pulsera presentaba problemas ya que la cadena que lo sujetaba se podía romper y extraviarse con facilidad. La pulsera tenía, sin embargo, un carácter más personal.

Estados Unidos: El ejército de los Estados Unidos reglamentó la utilización de placas de identificación a través de la Orden General No. 204, de 20 de diciembre de 1906.

"Una placa de identificación de aluminio, con el tamaño de medio dólar de plata y de espesor adecuado, sellada con el nombre, rango, compañía, regimiento o cuerpo del usuario, que será utilizado por cada funcionario y hombre alistado en el Ejército. La etiqueta debe ser suspendida del cuello, debajo de la ropa, por un cordón o correa que pase a través de un pequeño agujero en la ficha. Está prescrito como parte del uniforme y cuando no se lleve como se indica en este documento deberá mantenerse en la posesión del propietario. La etiqueta será facilitada por el Departamento de Suministros gratuitamente a soldados y a precio de costo a los oficiales..."

En 1916 se decidió que el soldado llevara dos placas: una para permanecer unida al cuerpo y la otra para informar a la persona a cargo de la inhumación con el fin de registrar su muerte. En 1918, el uso se extendió a todos los soldados alistados.

En la guerra de Vietnam, se autorizó a los soldados estadounidenses colocar una protección de goma para poder evitar el ruido de las placas al golpearse.

Otros países: En Rusia, las placas tuvieron formas diversas, tanto octogonal como oval. Se ideó, además, un sistema particular consistente en un tubo cilíndrico en el que se inserta otro tubo de menor diámetro donde se guardaba un documento de papel con los datos personales del soldado correspondiente.

En Italia se optó por un pequeño estuche metálico que se abría mediante una bisagra y que se pendía del cuello con una cuerda. En su interior se hallaba un desplegable de papel con un formulario que el soldado cumplimentaba con su nombre, regimiento, número, datos del día y lugar de nacimiento y dirección. Sistema similar fue implantado en Austria.

En Hungría también se adoptó el formato del pequeño estuche. En la cara anterior del mismo estaba grabada una cuadrícula cartesiana, en la que el soldado perforaba los dígitos de su número como soldado.

De todas maneras, en 1927, el Comité Internacional de la Cruz Roja definió los criterios para la estandarización de las placas de identificación con carácter universal.

\section{IDENTIFICACIONES A PARTIR DE HALLAZGOS DE PLACAS EN CONTEXTOS ARQUEOLÓGICOS}

La recuperación de estas placas junto a restos humanos en contextos de prospección o excavación arqueológica ha permitido identificar con su nombre e historia a numerosos soldados en diferentes episodios bélicos.

En los medios de comunicación y en la red se pueden documentar muchos ejemplos en los que una placa de identificación ha cumplido la finalidad para la que fue diseñada, identificar al soldado portador de la misma. Citamos a continuación una selección de varios casos, siguiendo un orden cronológico.

En la Guerra Civil americana (1861-1865) algunos soldados optaron por aprovechar antiguas monedas, en las que podían estampar los datos personales y convertirlas en placas de identificación personalizadas. Un ejemplo es la moneda española de dos reales de la época de Carlos III, en cuyo anverso se lee el nombre del soldado A. B. MINER (Colección Mike Brown).

En otro caso, en el reverso de una moneda conmemorativa dedicada a George Washington, se lee la leyenda: "EDWARD KELLY., CO.E., 16TH REG., WAR OF 1861, N.Y. S.V., DUNDEE.N.Y."

En 1985, los hermanos Clem descubrieron en una prospección realizada al oeste de Antietam Creek, en Washington County, un disco de identificación que perteneció a John Steven Thompson. Tiene el aspecto de una moneda por la orla exterior. En una de las caras se puede leer: "J.S. THOMPSON, C B, 3RD REG., VT. VOL. GLOVER.". En el reverso: "WAR OF 1861. UNITED STATES." El soldado John Steven Thompson había nacido el 29 de febrero de 1835 y vivió en Glover, Vermont. En 1861 se alistó voluntario en el ejército de la Unión con 26 años, en la Compañía $\mathrm{B}$, del Regimiento de Vermont, del $6^{\circ}$ Cuerpo de la armada de Potomac (Fig. 1).

En la cruenta batalla de Antietam, en septiembre de 1862, donde perecieron unos 23.000 soldados, el cabo John S. Thompson fue herido. De nuevo le hirieron en la batalla de Frederiksburg. En julio de 1863, cerca de Funkstown, el cabo Thompson perdió su disco de identificación. Falleció en 1900.

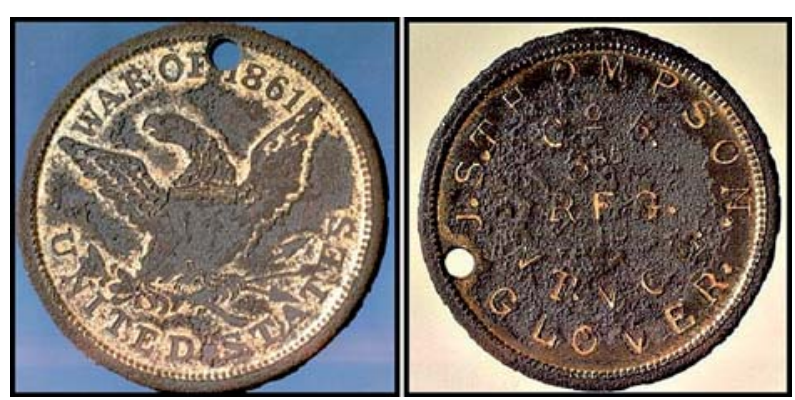

Fig. 1. Anverso y reverso de la placa de identificación de John Thompson, de la Guerra de Secesión americana. / Obverse and reverse of John Thompson's identity plate, from the American Civil War. 


\section{Primera Guerra Mundial}

Existen ejemplos de la Primera Guerra Mundial como consecuencia de exhumaciones de restos óseos de soldados fallecidos que, al tener asociada una placa de identificación, han posibilitado determinar su identidad y conocer aspectos biográficos de su existencia.

Con ocasión de la excavación realizada en el Canal Boezinge, en el área de trincheras en el saliente de Ypres (Bélgica), el grupo de arqueólogos conocidos como "The Diggers" han recuperado restos de 155 soldados de nacionalidad británica, francesa y alemana.

Sin duda, el hecho más destacable fue la exhumación en 2001 de los restos de dos fusileros galeses (Royal Welsh Fusiliers), abatidos en los primeros 7 meses de 1917. Aunque uno de los dos soldados fallecidos conservaba todavía su placa de identificación, no ha sido posible conocer la identidad porque el disco de asbesto estaba muy corrosionado.

La placa de identificación del soldado americano Kent Potter, natural de Chase County (Kansas), fue localizada en Liverdun (Lorena, Francia). Potter pertenecía a la Unidad 139, de la 134 División de Infantería, y consiguió sobrevivir a la contienda. La recuperación de la placa ha posibilitado recordar la historia de este soldado 94 años después.

En octubre de 2010 se inició la excavación de una línea de trincheras y de un túnel del ejército alemán en Carspach (Alsacia), bajo la dirección del arqueólogo Michael Landolt. El túnel Ilamado Kilian Shelter (Kilianstollen) estaba defendido por la $6^{\circ}$ Compañía de la Reserva de Infantería del Regimiento 94. En un ataque del ejército francés, llevado a cabo en marzo de 1918, la cubierta del túnel se desplomó y perecieron 34 soldados, de los cuales 13 fueron evacuados entonces. En la excavación se han localizado los 21 soldados restantes, algunos de los cuales portaban sus respectivas placas de identificación. Así han podido ser determinadas las identificaciones de, al menos, tres de ellos: el fusilero Martin Heidrich de Schönfeld, de 20 años; Harry Bierkamp, nacido 18 de enero 1896 en Hamburgo, y el teniente Hütten de Aachen, de 37 años (LANDOLT, 2013).

Sin embargo, la importancia del hallazgo de la placa de identificación se hace más patente, cuando no se encuentran en la exhumación, bien porque fueron sustraídos de los cadáveres cuando fueron enterrados o bien porque el material con el que se elaboraron las placas de identificación se ha deteriorado por agentes tafonómicos.

Un ejemplo de ello es el caso de Pheasant Wood o Bois Faisant (Fromelles, Francia). En este lugar la organización Oxford Archeology exhumó en 2007 un total de ocho fosas que contenían los restos de 250 soldados de la $61^{\circ}$ División británica y la $5^{\circ}$ División australiana, que murieron en los enfrentamientos del 19 y 29 de julio de 1916. Los cadáveres fueron enterrados por los soldados alemanes tras su victoria y la conquista del área. En la exhaustiva excavación realizada no se han recuperado placas de identificación, siendo probable que los propios enterradores les despojaran de sus placas de identificación (SUMMERS,
2013). Aún así se ha podido establecer la identificación de más de un centenar de soldados por técnicas genéticas.

\section{Segunda Guerra Mundial}

En relación con la Segunda Guerra Mundial, se puede citar el caso del hallazgo de dos placas de identificación (Dog Tags) pertenecientes a Oscar Glom, halladas en Italia, donde fue herido en 1944, aunque sobrevivió. Los objetos de este soldado americano de Texas fueron recuperados en Gavorrano por un prospector, quien se puso en contacto con la familia. Junto a las dos placas de identificación se hallaron un anillo, una medalla, dos tenedores y proyectiles. Los objetos fueron entregados al hijo de Oscar Glom, 66 años después.

Caso similar sería el descubrimiento en Normandía de la placa de identificación localizadas en el ático de una casa situada en la ruta de avance del ejército aliado tras el desembarco en la costa normanda en 1944. Pertenecía a Jason Riggs, del regimiento de ataque 576 estadunidense de Vadenberg, que desapareció en Francia.

En Francia un grupo de arqueólogos que trabajan en el campo de la Arqueología de Guerra (Battelfied Archeology), bajo la dirección del médico forense Jean-Loup Gassens, han exhumado e identificado varios soldados. Se trata de enterramientos clandestinos de soldados alemanes, en su mayor parte. Además de una actividad arqueológica e histórica, reivindican la función humanitaria de restituir los restos y darles una sepultura digna. En Villeneuve-Loubet, lugar próximo a Niza (Alpes Marítimos), hallaron en una zona boscosa una fosa común con restos de 14 soldados que murieron el 15 de agosto de 1944 . Entre los objetos asociados se encontraron cinco placas de identificación, que han permitido poner nombre a siete de dichos soldados.

\section{PLACAS DE IDENTIFICACIÓN EN ESPAÑA}

En el periodo anterior a la década de los años 20 del siglo XX, se usó una placa con un número dispuesto en pulsera que se sujetaba con una cadena o un brazalete de cuero. Estas piezas parecían objetos de joyería pues estaban fabricadas en plata o alpaca. En el anverso se disponía el escudo del arma al que pertenecía y en el reverso se hallaba grabado el nombre del soldado que lo portaba.

El alto número de bajas en el Monte Arruit del Rif en la batalla de Annual (1921), en el que la mayor parte de los cadáveres no pudieron ser identificados por el avanzado grado de descomposición, aceleró la aplicación de un sistema de identificación personal de los soldados. Ese mismo año se reglamentaba el uso de placas de identificación (Fig. 2):

\section{Orden de 17 de agosto de 1921}

SUBSECRETARIA.- Excmo. Sr.:- Reconocida la utilidad y gran importancia que tiene, en caso de guerra, la identi- 
ficación de bajas producidas en los combates, demostrado, recientemente, el resultado práctico proporcionado por el empleo de medallas de identidad, de las que estaban dotados los combatientes en la pasada guerra mundial, y llegada la ocasión de aprovechar tales enseñanzas, el Rey (q.D.g.) ha tenido a bien resolver lo siguiente:

1․ Se crea, con carácter reglamentario, la «Medalla de identidad del Ejército español»", cuyas características son: Disco de aluminio, de $24 \mathrm{~mm}$ de diámetro y de $2 \mathrm{~mm}$ de espesor. A dos milímetros del borde, un orificio de 5 $\mathrm{mm}$. de diámetro, para que por el mismo pase la cinta de suspensión. En una de las caras llevará estampado un número, cuyas cifras serán de $5 \mathrm{~mm}$ de altura.

$2^{\circ}$. Estas medallas se numerarán correlativamente del 1 al 100.000, dentro de cada una de las series precisas para dotar de ella a todo el Ejército, series que llevarán en la parte inferior del número una letra mayúscula de iguales dimensiones que las cifras, empezando por la $A$.

$3^{\circ}$. Se llevará en bandolera sobre la carne, de modo que quede a un costado.

4. Por la Fábrica nacional de armas blancas de Toledo se construirán las precisas para las necesidades actuales del Ejército, remitiéndose por lotes sucesivos a las Comandancias generales de Melilla, Ceuta y Larache. Una vez dotado el ejército de África, se hará lo propio con el de la Península, remitiéndolas a los correspondientes Capitanes generales.

5. Cada Capitanía o Comandancia general, una vez recibido el lote correspondiente, lo distribuirá por cuerpos, anotando en las correspondientes filiaciones el número de la medalla que a cada uno corresponda.

De real orden lo digo a V.E. para su conocimiento y demás efectos.- Dios guarde a V.E. muchos años.- Madrid 17 de agosto de 1921.

La primera placa tenía forma ovalada de $24 \mathrm{~mm}$ de diámetro y estaba realizada en aluminio. Era simétrica, porque se hallaba perforada en la zona media. Como únicos datos aparecía el número de expediente militar del interesado y una "E" dentro de un círculo.

Cumpliendo la orden anterior, las tropas indígenas de regulares fueron las primeras en utilizar placas de identificación. Eran ovaladas y tenían dos perforaciones en ambos lados, pues se habían diseñado para ser utilizadas como pulsera. Se grababa el número de serie del soldado, el emblema de regulares, y el número y población al que pertenecía.

En la Segunda República, bajo el gobierno de Azaña, se dictó una nueva Orden en 1931, que se adecuaba a la propuesta hecha por el Comité Internacional de la Cruz Roja de 1927.

\section{Orden Circular 1 de Septiembre de 1932}

ESTADO MAYOR CENTRAL SECCIÓN DE ABASTEClMIENTOS Y SERVICIOS. Sr.: la propuesta formulada por la comisión de recopilación y estudio del material sanitario, nombrado por orden circular de 5 de noviembre de 1931, relativa a elementos de identidad del personal y material sanitario y documentos sanitarios de vanguardia, este ministerio ha resuelto que los citados elementos y documentación, que comprenden: Placa y tarjeta de identidad, signo heráldico de la Cruz Roja, ficha médica de vanguardia, ficha médica de hospitalización, nomenclatura internacional de heridos y fichas-sobre de evacuación, cuyas instrucciones se detallan a continuación, se adopten con carácter reglamentario para el servicio sanitario en campaña.

Lo comunico a V.E. para su conocimiento y cumplimiento. Madrid 1 de septiembre de 1931. Azaña.

ELEMENTOS DE IDENTIDAD Y DOCUMENTACIÓN SANITARIA PARA EL SERVICIO EN CAMPAÑA A QUE SE REFIERE LA ORDEN QUE ANTECEDE ELEMENTOS DE IDENTIDAD

$1^{\circ}$ Del personal. a) Del ejército, b) de los servicios auxiliares de la sanidad militar

$2^{\circ}$ Del material sanitario

\section{a) IDENTIDAD DEL PERSONAL-PLACA DE IDENTIDAD}

Con objeto de poder identificar en todo momento $y$ principalmente al proceder a las inhumaciones y exhumaciones de cuantos pierdan la vida durante la prestación del servicio militar, todos los Generales, jefes y oficiales, así como los individuos de tropa en sus diferentes categorías, serán provistos de una placa de identidad, que se llevara permanentemente colgada al cuello, debiendo reunir, tanto la placa como el medio de suspensión, las características siguientes:

La placa de identidad debe estar hecha de una sustancia incombustible y resistente a los productos de la descomposición cadavérica, tendrá dos milímetros de espesor y de preferencia la forma oval $(40$ por $50 \mathrm{~mm})$, dividida en el sentido de su eje menor en dos mitades de igual superficie, por medio de una debilitación del metal que permitía realizar su ruptura, con relativa facilidad, sin necesidad de utilizar instrumentos.

La mitad superior que es por la que va suspendida al cuello, y que ha de permanecer unida al cadáver, está perforada por dos orificios situados cerca de su polo superior, destinado al paso del cordón, obligando con esta disposición a que la medalla quede siempre paralela a la superficie del cuerpo, mientras que la mitad inferior que es la parte destacable no llevará más que un orificio, a fin de ensartarla en un cordón o hilo metálico cuando se proceda a la separación de esa parte de la medalla a efectos de la identificación.

Además de la buena calidad, se exigirá confección esmerada, con los bordes limpios y exenta de rebordes cortantes.

Las inscripciones serán idénticas en las dos mitades, hecha con letras mayúsculas de las empleadas habitualmente en la escrita de imprenta y grabadas con profundidad; comprenderá: Sobre una de las caras los elementos de identidad del hombre: 
En cabeza una "E" encerrada en un óvalo, indicadora de nuestra nación (convención internacional de circulación automóvil de 1926).
a) Apellidos
b) El primer nombre y las iniciales de los demás, si los tuviera.
c) La religión en abreviatura o signo.

Sobre su otra cara, los elementos de su identidad militar:

a) Número de la filiación.

b) Reemplazo, fecha y lugar de nacimiento.

El cordón de suspensión al cuello deberá estar formado por hilos metálicos finos recubiertos de una envoltura de lana trenzada de color pardo oscuro o caqui.

Para los hilos metálicos no se empleará el plomo, cobre ni demás metales nocivos, recomendándose el uso de hilos de algodón, recubiertos de una capa de níquel.

La envuelta estará formada por una vaina de lana trenzada, considerándose como lo más aceptable la formada por veinticuatro hilos del número 32-32-2, en cuya trama se cuenten 15 por 16 por centímetro de longitud.

La resistencia de este cordón será 15 centímetros 12 kilos, con tres por ciento de diferencia admisible, y el peso de un metro de cordón 1.8 gramos con cinco por ciento de diferencia admisible, teniendo en cuenta un ocho por ciento de humedad.

Conforme en lo dispuesto en los artículos 4 de la convención de Ginebra de 1906 y 14 del reglamento anejo a la convención de la Haya (número 4) de 1907, la parte destacada de la placa de identidad encontrada sobre un muerto enemigo, debe de ser transmitida a la oficina prevista por estos artículos.

Para la impresión de estas fichas se dotará a los encargados de suministrarlas.

Sean las zonas de reclutamiento, Academias etc., según se determine, de unas cajas provistas de las letras y los números, convenientemente clasificados y en la proporción usual, ejecutados en acero, con los útiles necesarios para su empleo.

\section{PLACAS DE IDENTIFICACIÓN DURANTE LA GUERRA CIVIL (1936-1939)}

Aunque se definieron los respectivos tipos de placas, ninguno de los contendientes llegó a equipar a todos sus soldados debido a la carencia de metal suficiente o por problemas de fabricación. Muchos de los movilizados a la guerra sustituyeron de manera personal e improvisada la carencia de su propia placa o la suplieron por pérdida previa. Por todo lo anterior, existe una amplia variedad de placas de identificación.
Ejército franquista: Se mantuvo el diseño de la placa de identificación determinada en la Orden de 1931 (Fig. 3). En algunos casos, estas placas se personalizaban. En la Orden de 22 de enero de 1937, dictada por el ya nombrado Generalísimo Franco, se dan instrucciones para proceder al enterramiento de los soldados muertos en combate con la debida forma de identificación:

"Con objeto de que los enterramientos de personal fallecido en acción de guerra o accidente, se practique siguiendo las mismas normas en todos los frentes, que facilitan la debida identificación, acrediten el respeto que es debido a los caídos en la lucha y permiten la adopción de medidas higiénicas necesarias, deberán tenerse en cuenta las prescripciones siguientes:

Los enterramientos de los fallecidos en acción de guerra o accidente se efectuarán al ser posible, después de las veinticuatro horas y antes de las cuarenta y ocho siguientes a la ocurrencia de la muerte y una vez tomadas por el personal facultativo todas las precauciones para asegurarse que la muerte real se ha producido. El enterramiento tendrá lugar en el cementerio próximo de la ocurrencia, sí este no estuviera muy alejado del campo de batalla o lugar del accidente. .

El cadáver se enterrará con la parte superior de la medalla de identidad reglamentaria y si careciera de dicha medalla, se colocará entre las piernas, una botella taponada y dentro de la cual irá la filiación sucinta del inhumado. La documentación de los comentarios de guerra la llevará el Capellán....

Los Directores de Hospitales de Sangre pondrán especial cuidado con sus fallecidos para que al enterrarlos puedan ser siempre identificados siguiendo las normas señaladas"'.

Esta orden delata la preocupación existente por identificar a los contendientes durante el conflicto e incluso en el futuro tras su inhumación.

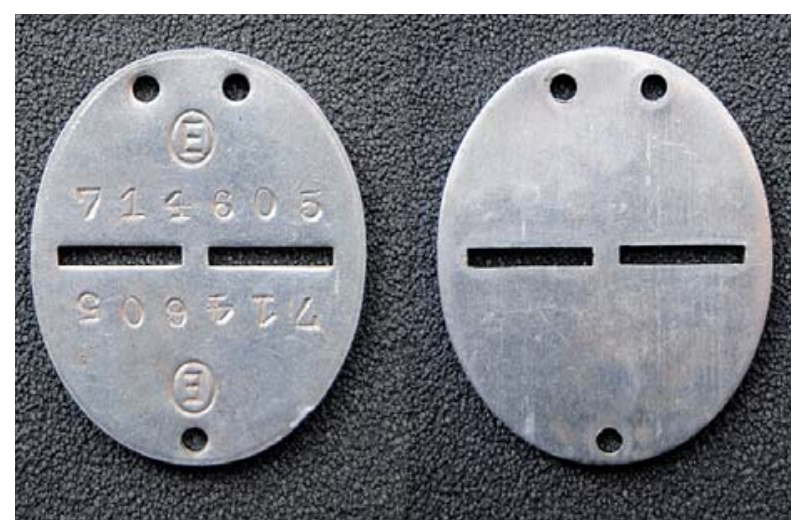

Fig. 2. Placa de identificación reglamentaria definida en las leyes de 1921 y $1931^{2}$. / Regulation identity plate as defined by the 1921 and 1931 laws $^{2}$.

\footnotetext{
${ }^{1}$ Las exhumaciones llevadas a cabo en el cementerio de la Prisión-Sanatorio de San Cristóbal en el monte Ezkaba (Navarra) han permitido conocer un ejemplo claro de aplicación de esta Orden en el conocido como Cementerio de las Botellas (HERRASTI y ETXEBERRIA, 2014).

${ }^{2}$ Publicada en la dirección: http://coleccindemedallas-serteco.blogspot.com.es/2012/11/placa-de-identidad-del-ejercito-espanol.html.
} 
Las placas venían prefabricadas con el número correlativo y la letra "E" dentro de un oval. Se distribuían en los diferentes frentes de batalla a los jefes de unidad para su reparto y control. Al tiempo se confeccionaban unas listas con el número asignado a cada soldado que eran recogidas y remitidas a un registro general. Estas listas debían ser renovadas con cierta periodicidad con la inclusión de las altas y bajas.

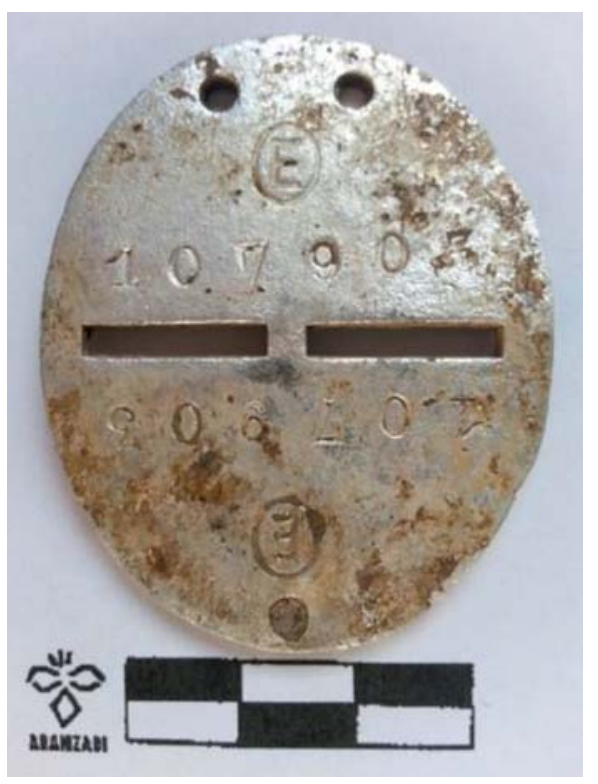

Fig. 3. Placa de identificación de aluminio utilizada en el ejército, localizada en el Monte Arangoiti en Apatamonasterio (E. Sardón). / Aluminium identity plate used in the army, found on Monte Arangoiti in Apatamonasterio (E. Sardón).

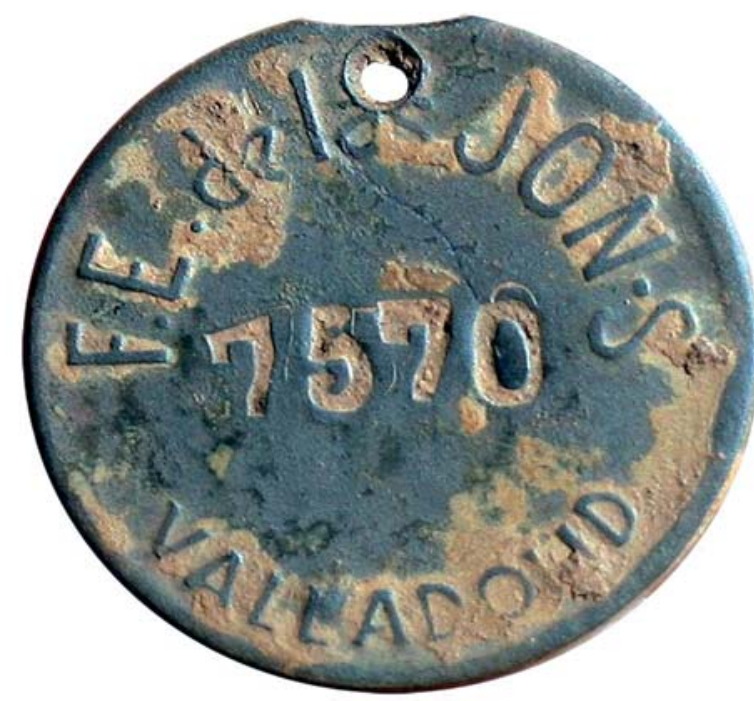

$2 \mathrm{~cm}$

Fig. 4. Chapa localizada en la paridera de Enebrá Socarrá en Abánades (Guadalajara) (Foto: Alfredo González-Ruibal. CSIC). / Plate found in Enebrá Socarrá lambing pen, in Abánades (Guadalajara) (Photo: Alfredo GonzálezRuibal, CSIC).
Además de las placas reglamentarias militares, también se utilizaron otras de grupos de formaciones políticas o laborales. Así son conocidas las empleadas por miembros de Falange Española de las JONS que poseían una específica. En ella, además de la mención de Falange en la orla externa, se añadía el número de registro del miembro correspondiente y la provincia en la que se había alistado. Una de esas placas ha sido recuperada en la excavación, dirigida por Alfredo González-Ruibal, llevada a cabo en la paridera Enebrá Socarrá, en Abánades (GONZÁLEZ-RUIBAL, 2012) (Fig. 4).

También poseían sus propias placas de identificación los soldados alemanes e italianos que combatieron a favor de los franquistas en la Guerra Civil española. Con ocasión de la remodelación del cementerio de Campillo de la Serena (Badajoz), Ilamado Cementerio de los Italianos, porque fue construido por la I Brigada Mixta de los Flechas Azules en 1937, se han recuperado cuatro placas de identificación características del ejército franquista ${ }^{3}$.

Una serie importante de placas fue elaborada para los integrantes de la División Azul que lucharon en el frente este de Europa durante la Segunda Guerra Mundial. Este tipo de placas es similar al modelo alemán, de forma ovalada (40 por $50 \mathrm{~mm}$ y $2 \mathrm{~mm}$ de espesor) y con ranuras en la zona media para facilitar la ruptura en dos mitades. Los datos grabados se repiten en ambas partes: el número correspondiente al soldado, Span. Div. (Spanien Division) y la unidad a la que pertenecía. Siguiendo la costumbre germana, la placa se guardaba en una cartera de cuero que iba suspendida del cuello (Fig. 5 y 6 ).

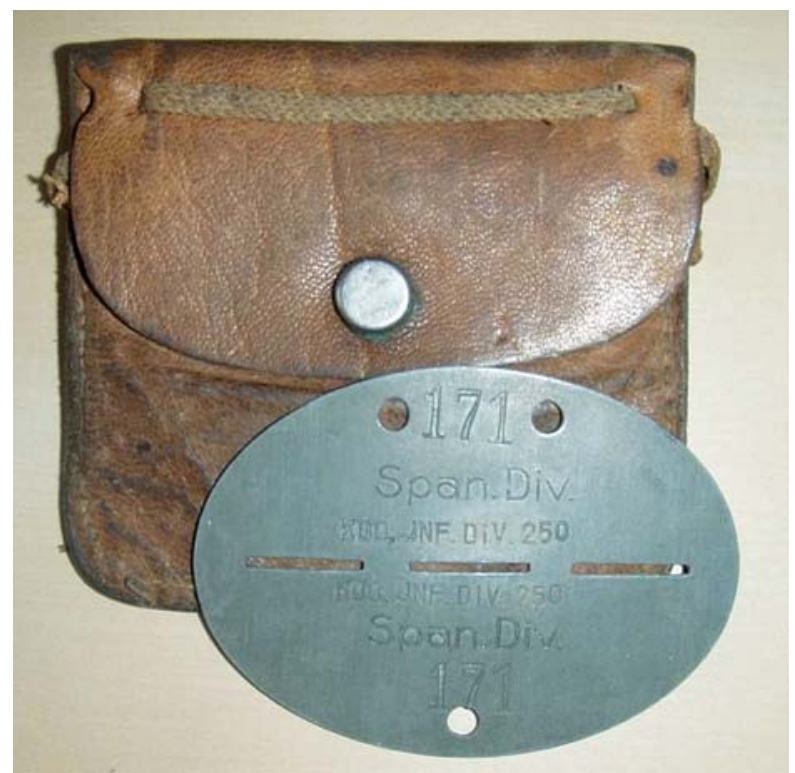

Fig. 5. Estuche de cuero para guardar la placa de identificación de un soldado de la División Azul. / Leather case for the dog tag of a soldier in the Blue Division. 


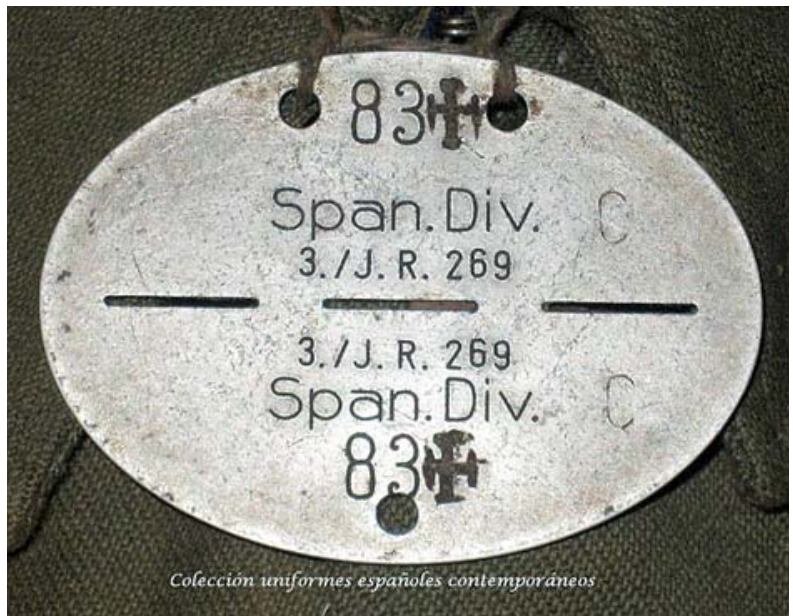

Fig. 6. Placa de la División Azul recuperada en las exhumaciones del 2012. ${ }^{4}$ / Blue Division dog tag found in the 2012 exhumations. ${ }^{4}$

Contando con el apoyo del Ministerio de Defensa, el Servicio Alemán de Tumbas de Guerra (Volksbund Deutsche Kriegsgäberfürsorge, VDK) viene realizando exhumaciones de soldados españoles que murieron en la zona de Novgorod (Federación de Rusia). El año 2012 se recuperaron un total de 173 placas identificativas que fueron depositadas en el Archivo General Militar de Ávila. Las tareas de exhumación han tenido continuidad en 2014.

En la actualidad, el uso de placas de identificación personal está regulado oficialmente y una de las últimas disposiciones la encontramos en la orden del Ministerio de Defensa, firmada por el Jefe de Estado Mayor del Ejército del Aire, del 13 de julio del 2000 y publicada en el 18 de agosto de dicho año (B.O. Ministerio de Defensa 218/2000).

Ejército republicano: Existía una mayor variedad tanto en forma como en material. En su mayoría eran metálicas de forma circular, con una o dos perforaciones, para ser colgadas del cuello o para ser portadas como muñequeras (Fig. 7).

Al igual que en otros modelos, se grababa el número de registro como combatiente y en algunas ocasiones las iniciales del nombre, además de la mención al batallón. Algunas placas tenían un rebaje en la zona media lo que facilitaba la fractura en caso de ser necesario. También hay ejemplos de placas improvisadas reutilizando monedas de curso legal, como la moneda de 50 céntimos de la época.

\section{PLACAS DE IDENTIFICACIÓN EN EL PAÍS VASCO DURANTE LA GUERRA CIVIL}

\subsection{Contexto histórico}

Iniciada la guerra, se aprobó el Estatuto vasco el 1 de octubre de 1936. Así, el 7 de octubre se conformó el primer Gobierno vasco con la toma de posesión del Lehendakari José Antonio Agirre Lekube.

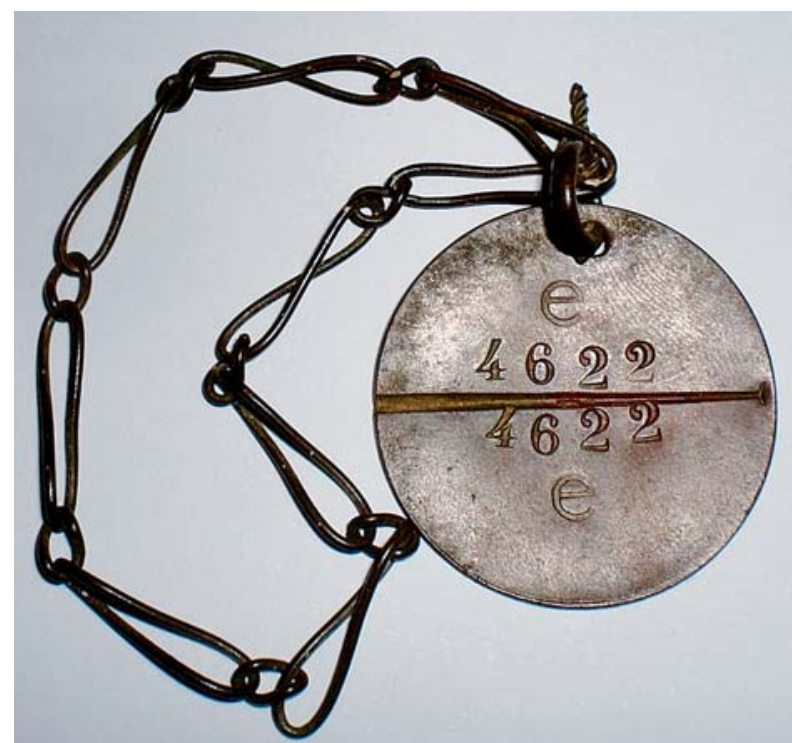

Fig. 7. Placa del ejército republicano. (Foto: David Ramírez). / Republican army dog tag (Photo: David Ramírez)

Sin embargo, meses antes, el día 8 de agosto, la Junta de Defensa Nacionalista reunida en Azpeitia hizo un llamamiento público para el alistamiento voluntario de gudaris para luchar contra los sublevados. Así se constituyó el Euzko Gudarostea o Ejército vasco., que se puso bajo el mando del comandante Cándido Saseta.

Al igual que el gobierno era de concertación, compuesto por consejeros de cinco partidos de diferente ideología, también el Eusko Gudarostea estuvo conformado por batallones de distintos partidos, tanto nacionalistas, como socialistas, comunistas, anarquistas y republicanos. Así, los batallones que figuraban en la orden del 26 de abril de 1937 con mando militar unificado en el Eusko Gudarostea eran (VARGAS ALONSO, 2001):

\section{EAJ-PNV: 25 batallones \\ 2. PSE y UGT: 11 batallones. \\ 3. JSU: 9 batallones \\ 4. EPK-PCE: 8 batallones.}

5. Sin filiación: 7 batallones. Montaña №1, Montaña №2, Montaña №3, Artillería Ligera №3, Grupo Antiaéreo, Transmisiones, Batallón de carros de asalto.

\section{CNT: 7 batallones. \\ 7. IR: 5 batallones. \\ 8. ANV: 4 batallones. \\ 9. Jagi-Jagi: 2 batallones. \\ 10. ELA-STV: 1 batallón.}

11. Republicanos: 1 batallón.

${ }^{4}$ http://uniformesp.blogspot.com.es/2011/11/voluntario-de-la-division-azul-1941.html 
En total se movilizaron unos 60.000 hombres, de los cuales el $80 \%$ tenía entre 20 y 30 años. A lo largo de la guerra unos 7.000 milicianos perdieron la vida.

La guerra desarrollada en territorio vasco puede dividirse en tres periodos:

1. Desde el 18 de julio de 1936 hasta el 7 de octubre en que se constituyó el Gobierno vasco, por la que el ejército vasco paso a estar bajo la autoridad del propio lehendakari como Consejero de Defensa.

2. Del 7 de octubre hasta el 31 de marzo de 1937. Durante este periodo el frente estuvo estabilizado en la línea Deba-Elgoibar- Intxortas.

3. De abril de 1937 hasta la caída de Bilbao, el 19 de junio de 1937. El avance del ejército franquista fue constante y muy intensa la crudeza de los enfrentamientos, pues la lucha fue implacable en la defensa de las distintas cotas y cimas de montes en Bizkaia (Saibigain, Bizkargi, Sollube, Peña Lemona y Artxanda).

La mayor parte de los cadáveres de los soldados muertos en combate eran recogidos y trasladados a lugares de enterramiento, como fosas comunes, cementerios improvisados $u$ otros ya existentes en los pueblos cercanos. De esta tarea se encargaban brigadas específicas de soldados, peones camineros o los propietarios de los terrenos que agrupaban varios cuerpos y los in- humaban en fosas comunes. Así ocurrió en Ziardamendi (Elgoibar), donde el propietario del monte, del caserío Ziarda, distribuyó los cadáveres en al menos cuatro lugares de inhumación. En una de ellas, y por indicación de su hijo Victoriano Agote, se localizó una fosa de cuatro individuos que fue exhumada en 2012 (ETXEBERRIA, 2014). La muerte de estos gudaris, alistados días antes, tuvo lugar el 25 de septiembre de 1936, lo que explica que carecieran de placas de identificación.

En Etxaguen (Álava/Araba) se exhumó en 2013 una fosa que contenía de 12 a 15 milicianos inhumados en la parte posterior de la iglesia parroquial. Según testimonios de los vecinos, los cadáveres de los soldados habían sido recogidos en una casa en la que estalló un mortero y trasladados en una carreta hasta el lugar donde fueron volcados y enterrados (Fig. 8). Posiblemente se trate de milicianos de un batallón comunista de UHP.

\subsection{Registro de los nombres y números de placas}

Conformado el ejército vasco, fue necesario equipar a todos los soldados y gudaris con indumentaria: uniformes, calzado, correajes, cinturones; material militar: cartucheras, armas, cascos, ...; y material personal: placa de identificación, galones...

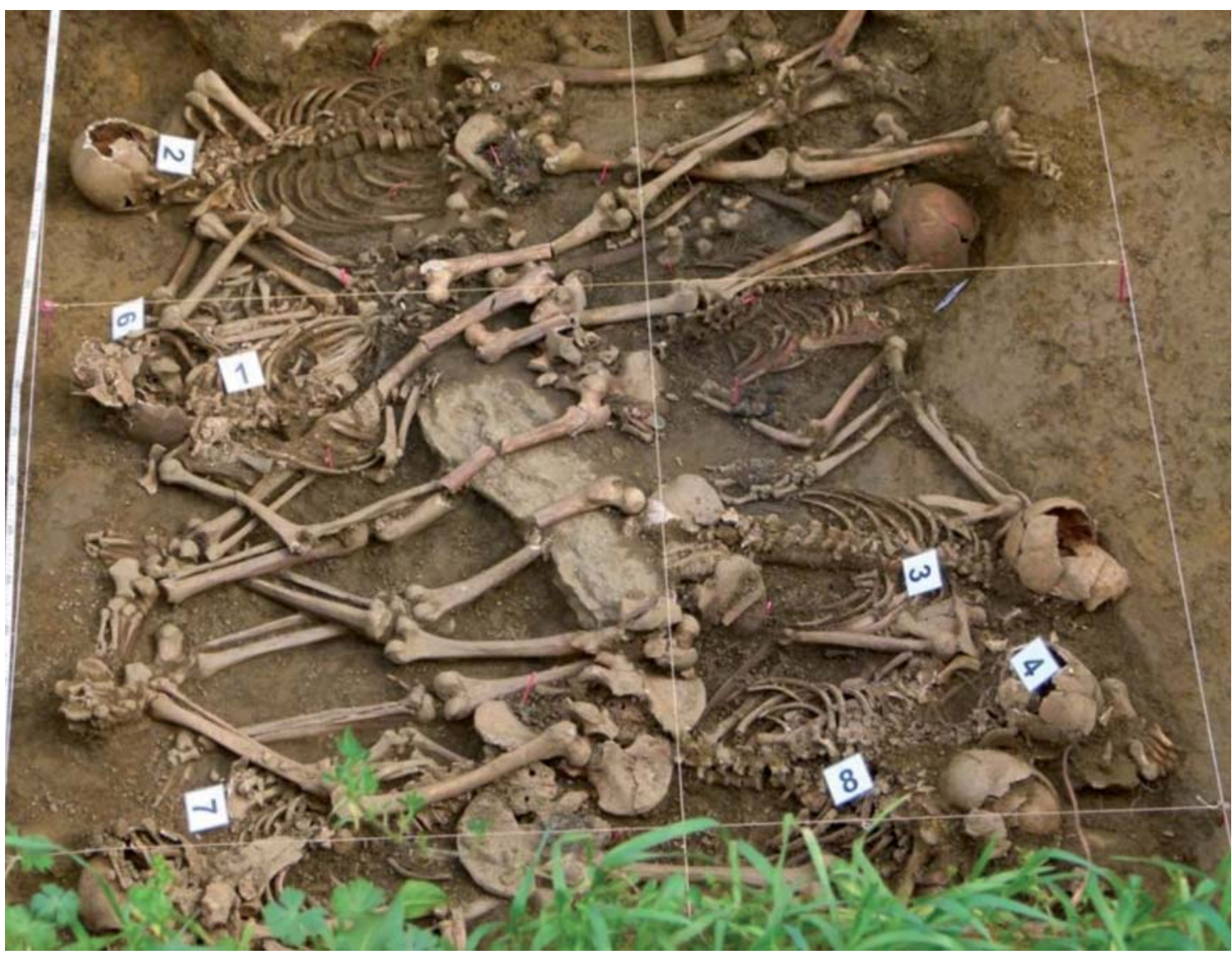

Fig. 8. Fosa de combatientes de Etxaguen/Zigoitia (Álava). / Soldiers' mass grave in Etxaguen/Zigoitia (Álava). 
Así pues, entre los objetos entregados se hallaba la placa de identificación que se determinó fuera un disco metálico circular de $2 \mathrm{~cm}$ de diámetro, con un orificio que permitiera ser suspendido de un cordel del cuello o con doble perforación en los laterales para ir llevarlo como muñequera ${ }^{5}$.

Para el adecuado registro y documentación se elaboraban fichas donde se recogían los datos del miliciano, al que se le asignaba un número de alistamiento, que coincidiría con el número de la placa y el número a través del que se pagarían las nóminas como soldado (Fig. 9).

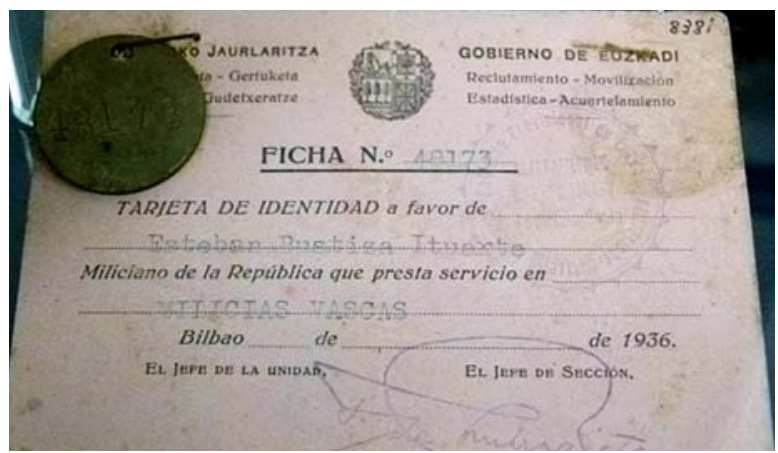

Fig. 9. Ficha de registro con el número de gudari y la placa correspondiente. (Archivo Fundación Sabino Arana). / Record file with the militiaman's number and the corresponding dog tag (Sabino Arana Foundation archive).

\subsection{Tipos de placas identificativas recuperadas en el País Vasco}

El tipo de placa más común consistió en un disco de $2 \mathrm{~cm}$ que iba remachado en los laterales y trabada a una muñequera o brazalete de cuero (Fig. 10). Ejemplos de este tipo se conservan en el Museo de Amigos de Laguardia, con los números 31541 y 18094. A este mismo modelo corresponderían las placas con las numeraciones 28078, 30492, 46164 y 63377.

También están presentes las placas circulares con un solo orificio en la parte superior que permitía fueran sus-

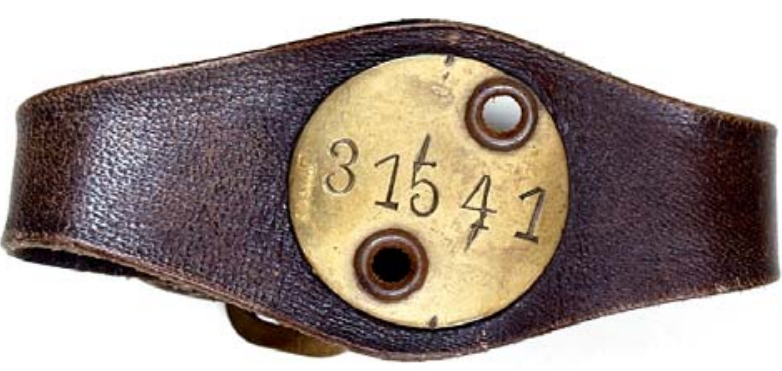

Fig. 10. Tipo de placa más habitual. Engarzada en una muñequera de cuero. (Museo de Amigos de Laguardia). / Most usual form of identity plate, riveted to a leather wrist strap (Friends of Laguardia Museum). pendidas del cuello con un cordel. De este tipo se han recuperado las placas con los números 35730, 44284, 49425, 78505, 78539 y 84481 . En algunas placas se observa que, además de la perforación se le ha añadido otro orificio más tosco en el lado opuesto, de manera que la placa pudiera ser sujeta por los dos extremos, posiblemente en la muñeca. Así, son muestra de ello las que tienen los números 29294, 65630, y 1165. En este último ejemplo, el ojal hecho manualmente está abierto, por lo que fue necesario realizar un $3^{\circ}$ orificio en la zona central del disco. Un ejemplo similar se observa en la placa con el número 13312. (Tabla 1)

Existen, asimismo, un tipo de placas peculiares de modelos casi exclusivos. A veces, se reaprovechaban discos metálicos de establecimientos comerciales como el ejemplo de la placa de aluminio de un local existente en Bilbao denominado "La Terraza". El disco conserva en el anverso el nombre y en el centro el número 205. En el reverso, quien reutilizó la placa grabó su número de soldado, aunque en la actualidad resulta ilegible.

A la altura de la muñeca del Individuo n’3 de la fosa 1 de Antzuategi (Elgeta) se recuperó una placa de identificación realizada en una moneda de 2 pesetas del Gobierno de Euzkadi (1937).

Un modelo distinto de placa metálica de forma cuasirectangular es en el hallado en el monte Ganzabal y con el nombre de su titular B.S.M.

El tipo de placa más elaborado es de latón rectangular y extremos en ángulo con dos lengüetas laterales para los orificios. En una de las caras se ve con claridad el número 37517 y en la otra grabado con grafía esmerada "L. Uriarte" (Fig. 11a). Está engarzada en una cadena también metá-

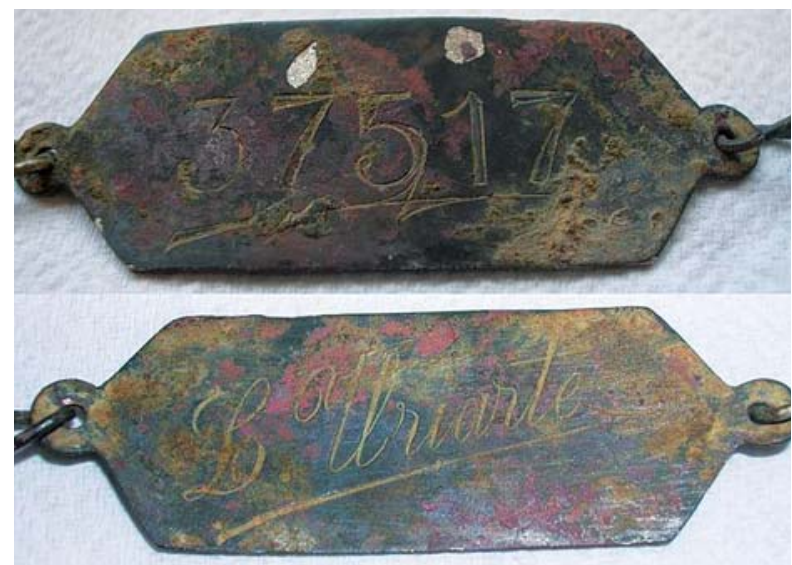

Fig. 11a. Anverso y reverso de la placa tipo pulsera de L. Uriarte y n 37517. / Obverse and reverse of the wrist-strap plate belonging to L. Uriarte, with the number 37157.

\footnotetext{
${ }^{5}$ En el artículo escrito por Iban G. González en el diario Deia del 5 de mayo de 2013, con ocasión del hallazgo de una placa de identificación en Ganzabal, se recogen los testimonios de varios gudaris y milicianos que portaron placas identificativas. Así a Félix Padín, anarquista que fue teniente y sargento en los batallones Isaac Puente y Durriti, le correspondía el número 6077. A Manuel Sagastibeltza del batallón Abellaneda del PNV le sustrajeron su respectiva placa en el campo de concentración de San Juan de Mozarrifar (Zaragoza), donde fue recluido. Pero no todos los gudaris y milicianos dispusieron de una chapa, como indicaron en el mismo artículo José Moreno, del batallón San Andrés de STV, y Juan Azcárate, de la Marina Auxiliar de Guerra. Numerosos emblemas, placas de identificación, hebillas, tanto de distintas milicias como del Ejército y Euzko Gudarostea, se fabricaron en Gernika-Lumo en la empresa Joyería y Platería de Guernica S.A. (comunicación personal de Txato Etxaniz).
} 


\begin{tabular}{|c|c|c|c|c|}
\hline \multicolumn{5}{|c|}{ Placas de identificación halladas en el País Vasco } \\
\hline Número & Lugar de hallazgo & Identidad & Batallón & Depósito \\
\hline \multicolumn{5}{|c|}{ Placas recuperadas en exhumaciones } \\
\hline 71513 & Antzuategi. Fosa 1 Elgeta & J.Z.M. & Dragones & S.C. Aranzadi \\
\hline 71228 & Ganzabal. Fosa & E.B.L. & Dragones & Entregada a la familia \\
\hline 11104 & Monte Ganzabal & B.S.M. & Brigada 13 ANV-1 & Joseba Diéguez \\
\hline 72865 & Peña Lemona (Lemoatz) & H.B.R. & B. 28 Barakaldo & S.C. Aranzadi (pendiente de entrega) \\
\hline \multicolumn{5}{|c|}{ Hallazgos en prospecciones } \\
\hline 78539 & Monte Mirugain & & & A.J.S. \\
\hline ¿XX46? ¿XX16? & Monte Astaiz & & & A.J.S. \\
\hline 84481 & Monte Arrietabaso & & & A.S. \\
\hline 49425 & Monte Saibigain & & & A.S. \\
\hline 13312 & Monte Albertia & & & A.S. \\
\hline 46164 & Monte San Pedro de Urkabustaiz & & & A.S. \\
\hline 28078 & Monte Eskubaratz & & & E.S. \\
\hline 29294 & Siskiñe. Sector Ubidea & & & J.D. \\
\hline 108336 & Monte San Bernabé & & & J.D. \\
\hline 1165 & Monte Albertia & H.B.B. & Barakaldo & J.D. \\
\hline 63377 & Monte Betaio & & & J.D./A.I. \\
\hline 30492 & Jarindo & & & J.E. \\
\hline 37517 & Kalamendi & L.U. & & J.E. \\
\hline 65630 & Mina Sta. Lucía Udalaitz & & & J.E. \\
\hline 39349 & Berretin & & & J.E. \\
\hline 35730 & Monte Kolitza & & & D.R. \\
\hline 78505 & Tantaibakar & & & X.LL. \\
\hline 77882 & Monte Betaio & & & A.S. \\
\hline 13295 & ¿? & & & A.S. \\
\hline 107903 & Monte Arangoiti & & Ejército Franquista & E.S. \\
\hline \multicolumn{5}{|c|}{ Entregadas por familiares y en depósito de museos } \\
\hline 48173 & & E.B.I. & Milicias Vascas & Fundación Sabino Arana \\
\hline 31541 & & & & Museo de Amigos de Laguardia \\
\hline 18094 & & & & Museo de Amigos de Laguardia \\
\hline 81491 & & & & Museo de Etnografía, Bilbao \\
\hline 1146 & & L.G.A. & & Museo de Etnografía, Bilbao \\
\hline 44284 & & J.A.B. & ANV-2 & Familia Andonegi \\
\hline 69045 & & J.A.O. & Amaiur & Familia Amozarrain \\
\hline
\end{tabular}

lica, por lo que se asemeja a una pulsera de joyería. Similar a la anterior es la placa con el número 69045. En su reverso está grabado el nombre del propietario "J. Amozarrain. Arrasate", gudari perteneciente al batallón Amaiur.

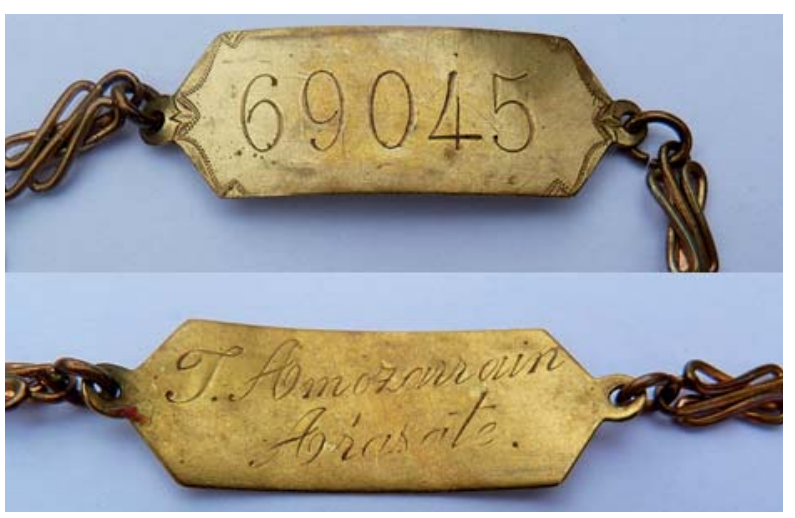

Fig. 11b. Anverso y reverso de otra placa-pulsera de J. Amozarrain y $\mathrm{n}^{\circ}$ 69045. / Obverse and reverse of the wrist-strap plate belonging to $\mathrm{J}$ Amozarrain and number 69045.
En cuanto a los tipos de sujeción de las placas, parece que lo más común consistió en cuerda retorcida en cordel, o en fibras metálicas forradas de tejido de lana. En algunos casos, son cadenas de anillos metálicos, como el ejemplo recuperado en la exhumación de Lemoatz.

\section{PLACAS DE IDENTIFICACIÓN RECUPERADAS EN EXHUMACIONES DE COMBATIENTES EN EL PAÍS VASCO}

A lo largo de los últimos años se han realizado en España 379 exhumaciones de fosas comunes y se han recuperado 6680 esqueletos (datos de septiembre de 2014). El 4\% de estas fosas corresponden a enterramientos en zonas de combate.

Las exhumaciones de combatientes que se mencionan a continuación se situarían en la última fase de la Guerra Civil en territorio vasco, en la que el avance y retroceso de las tropas en lucha provocó que muchos cadáveres quedaran en tierra de nadie y no pudieran ser evacuados (ARTECHE, 1970). 


\section{Antzuategi. Fosa 1. Elgeta}

Durante el mes abril de 1937 se intensificaron los ataques de las tropas franquistas en la línea de frente del área de Intxortas y Asensiomendi. Las posiciones republicanas fueron cediendo terreno y el avance rebelde, cuya vanguardia estaba formada por los regulares, alcanzó Elgeta el sábado 24 de abril.

Los hermanos Joxe Bixente y Biktor Garai Aranzeta, que vivían en el caserío Antzuategi (Elgeta, Gipuzkoa), relataron los sucesos de ese día. "A las 16:00 horas entraron los fascistas en Elgeta y detuvieron a 6 gudaris, que se habían refugiado en nuestro caserío. Esa noche fusilaron a los soldados y a nuestro padre. Les enterraron cerca del caserío en dos oquedades que habían provocado las bombas del incesante bombardeo al que estuvo sometida toda la zona. El cadáver de nuestro padre pudo ser inhumado en el cementerio, porque nuestra madre consiguió recuperarlo a cambio de una marmita de leche."

En el mes de junio de 2004 se procedió a la exhumación de dos fosas, donde habían sido inhumados los seis milicianos. La Fosa 1 estaba ubicada a escasos metros del caserío. Tal y como habían dicho los informantes, se había aprovechado una zona socavada en el terreno y en ella estaban enterrados tres individuos, dos en posición decúbito supino y un tercero en decúbito prono (Fig. 12). Se trataba de hombres jóvenes, de edades comprendidas entre los 19 y 35 años.

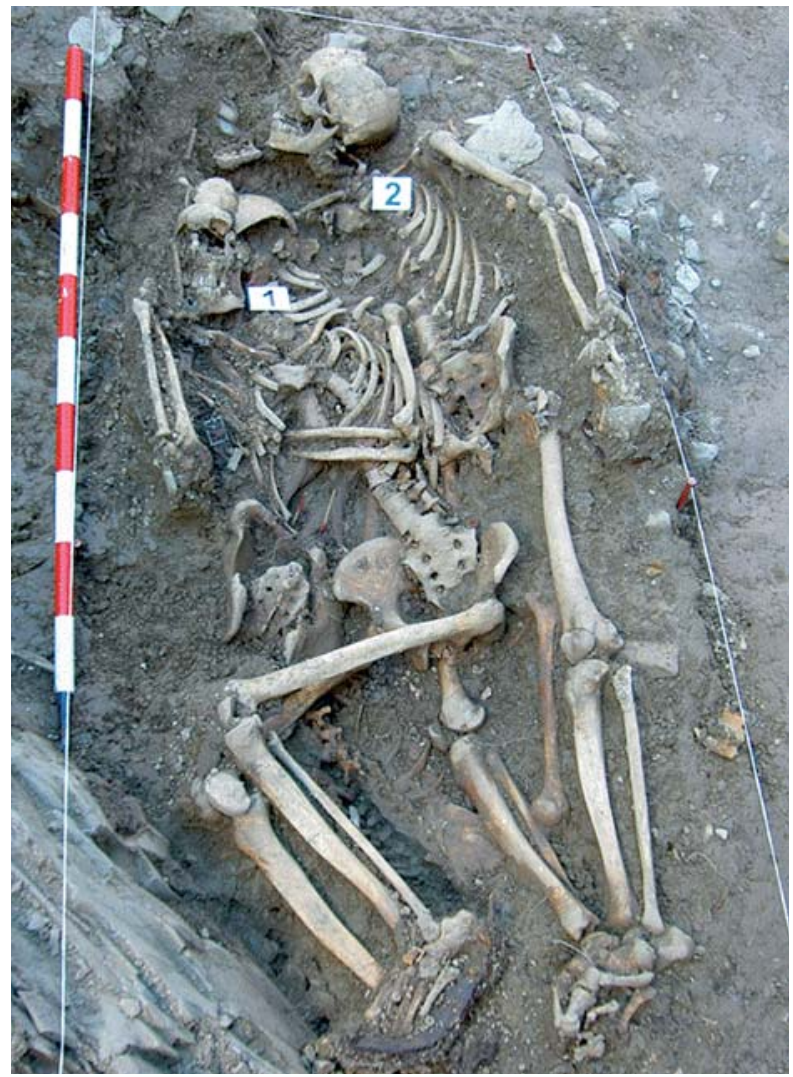

Fig. 12. Antzuategi Fosa 1 (Elgeta, Gipuzkoa). / Antzuategi Grave 1 (Elgeta, Gipuzkoa).

\begin{tabular}{|c|c|c|}
\hline \multicolumn{3}{|c|}{ ANTZUATEGI. FOSA 1.} \\
\hline & Objetos asociados & Lesiones \\
\hline $\begin{array}{l}\text { IND. } 1 \\
25-30\end{array}$ & $\begin{array}{l}\text { - Hebilla-placa del Gobierno Vasco } \\
\text { - Cuchara latón y tenedor } \\
\text { de aluminio } \\
\text { - Enganches metálicos correajes } \\
\text { - Dos hebillas } \\
\text { - Suelas de botas de cuero } \\
\text { - Dos fragmentos de metralla }\end{array}$ & $\begin{array}{l}\text { - Herida de arma de fuego en } \\
\text { coxal derecho. Fragmento de } \\
\text { metralla a su lado. } \\
\text { - C1 y C2 paso de proyectil } \\
\text { - Fractura consolidada en meta } \\
\text { carpianos }\left(1^{\circ} \text { a } 4^{\circ}\right) \text { de mano izda. } \\
\text { por aplastamiento. }\end{array}$ \\
\hline $\begin{array}{l}\text { IND. } 2 \\
30-35\end{array}$ & $\begin{array}{l}\text { - Llave de } 104 \text { mm longitud, } \\
7 \text { de grosor del vástago y } 21 \text { de } \\
\text { anchura máxima. } \\
\text { - Llave de armario. } \\
\text { - Anillo de } 22 \text { mm de aro de oro, } \\
\text { de } 1 \mathrm{~mm} \text { de grosor. Piedra } \\
\text { granate en cabujón de oro. } \\
\text { - Lápiz. } \\
\text { - Hebilla de tracción de correaje. }\end{array}$ & $\begin{array}{l}\text { - Paso proyectil zona media } \\
\text { radio dcho. } \\
\text { - Paso de proyectil cerca } \\
\text { de ángulo mandibular derecho. } \\
\text { - } 3^{\circ} \text { metacarpiano dcho. } \\
\text { callo con angulación. } \\
\text { - Erosión frontal en mitad dcha. } \\
\text { Del frontal. }\end{array}$ \\
\hline $\begin{array}{l}\text { IND. } 3 \\
19-24\end{array}$ & $\begin{array}{l}\text { - Moneda de } 2 \text { pesetas del } \\
\text { Gobierno de Euzkadi con el } \\
n^{\circ} 71513 . \\
\text { - Reloj de pulsera de oro y acero. } \\
\text { - Mechero cilíndrico de tapa } \\
\text { de rosca. } \\
\text { - Botones de abrigo. }\end{array}$ & $\begin{array}{l}\text { - Paso de proyectil en esternón } \\
\text { y en dos costillas del costado } \\
\text { dcho. } \\
\text { - Entrada por delante y } \\
\text { perpendicular. } \\
\text { - Fractura diáfisis fémur izdo. } \\
\text { - Fractura de diáfisis de cúbito } \\
\text { dcho. }\end{array}$ \\
\hline
\end{tabular}

El aspecto más destacado de esta exhumación consistió en el número y calidad de objetos que poseían (OLSEN, 2010), que se relacionan a continuación (Fig. 13).

\section{Antzuategi (Elgeta). Individuo 1:}

Hebilla de cinturón de latón con escudo del Gobierno Vasco de 75 por $50 \mathrm{~mm}$. Cuchara de latón oxidada de 187 $\mathrm{mm}$ de longitud. Tenedor de aluminio de $155 \mathrm{~mm}$. Dos enganches metálicos de cinturón de 30 por $35 \mathrm{~mm}$. Hebilla de latón de 33 por $40 \mathrm{~mm}$, un enganche y parte de cinturón de material rojizo. Dos apliques metálicos de latón de $25 \mathrm{~mm}$ de longitud, con cuatro orificios para ser cosidos a una tela. Cuatro botones de nácar de $10 \mathrm{~mm}$. Botón negro de pasta de $25 \mathrm{~mm}$. Suelas de bota de cuero con tachuelas metálicas. Dos fragmentos de metralla.

\section{Antzuategi (Elgeta). Individuo 2:}

Llave de 104 mm longitud, 7 de grosor del vástago y 21 de anchura máxima. Llave tubular de cuerda, como los del tipo de reloj de pared, o de armario de $63 \mathrm{~mm}$, por 4 de grosor y 27 de anchura en la cabeza. Anillo de $22 \mathrm{~mm}$ de aro, de oro, de $6 \mathrm{~mm}$ de ancho y $1 \mathrm{~mm}$ de grosor. Piedra granate en cabujón de oro de forma ovalada, de $10 \mathrm{~mm}$ de diámetro máximo y $8 \mathrm{~mm}$ de altura, en buenas condiciones. Lápiz de color violáceo, quebrado en ángulo. Hebilla de tracción de los correajes.

\section{Antzuategi (Elgeta). Individuo 3:}

Placa de identificación elaborada con una moneda de 2 pesetas del Gobierno de Euzkadi con el número 71513. 


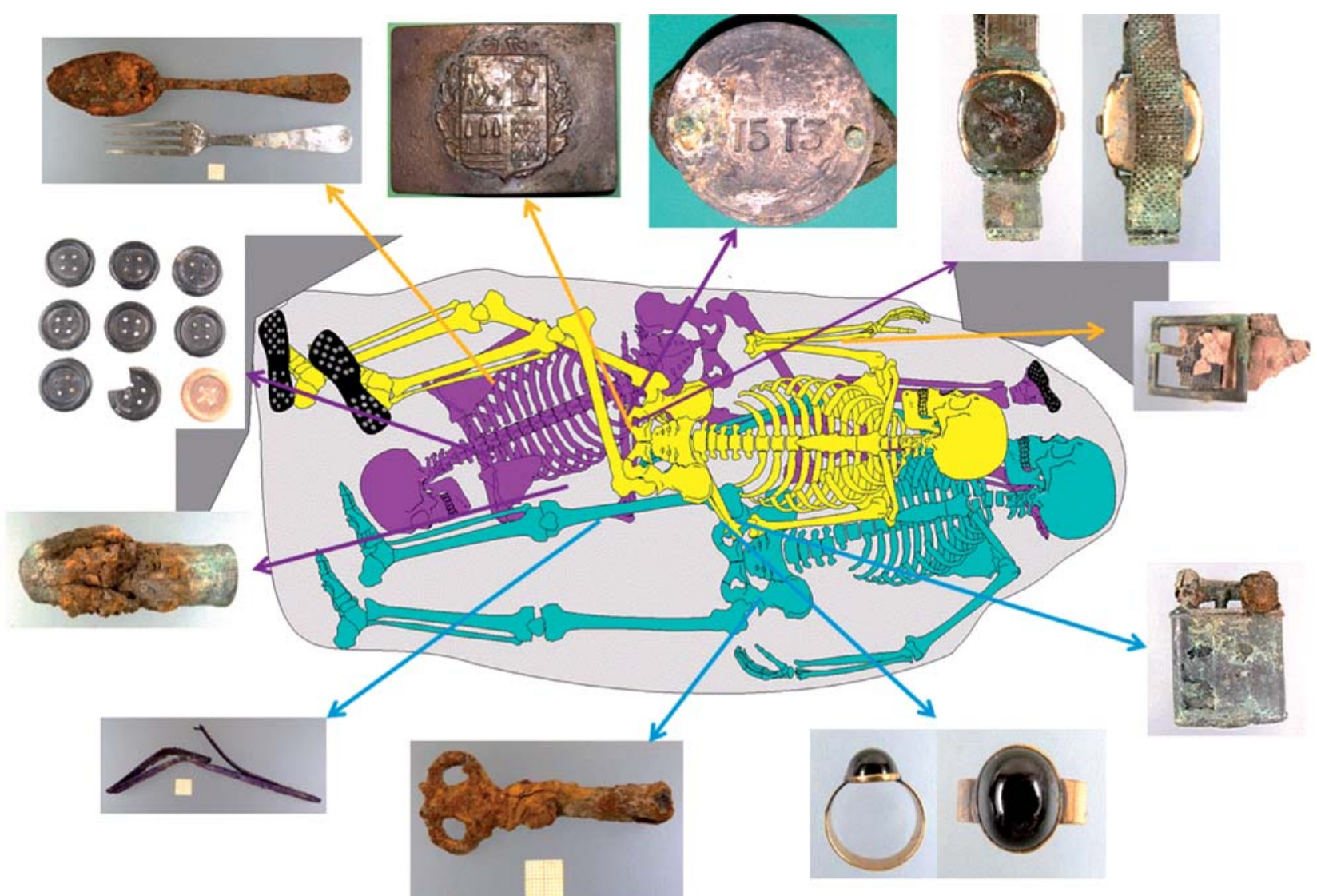

Fig. 13. Objetos recuperados en la Fosa 1 de Antzuategi en relación a cada individuo. / Objects found in Antzuategi Grave 1, associated with each individual.

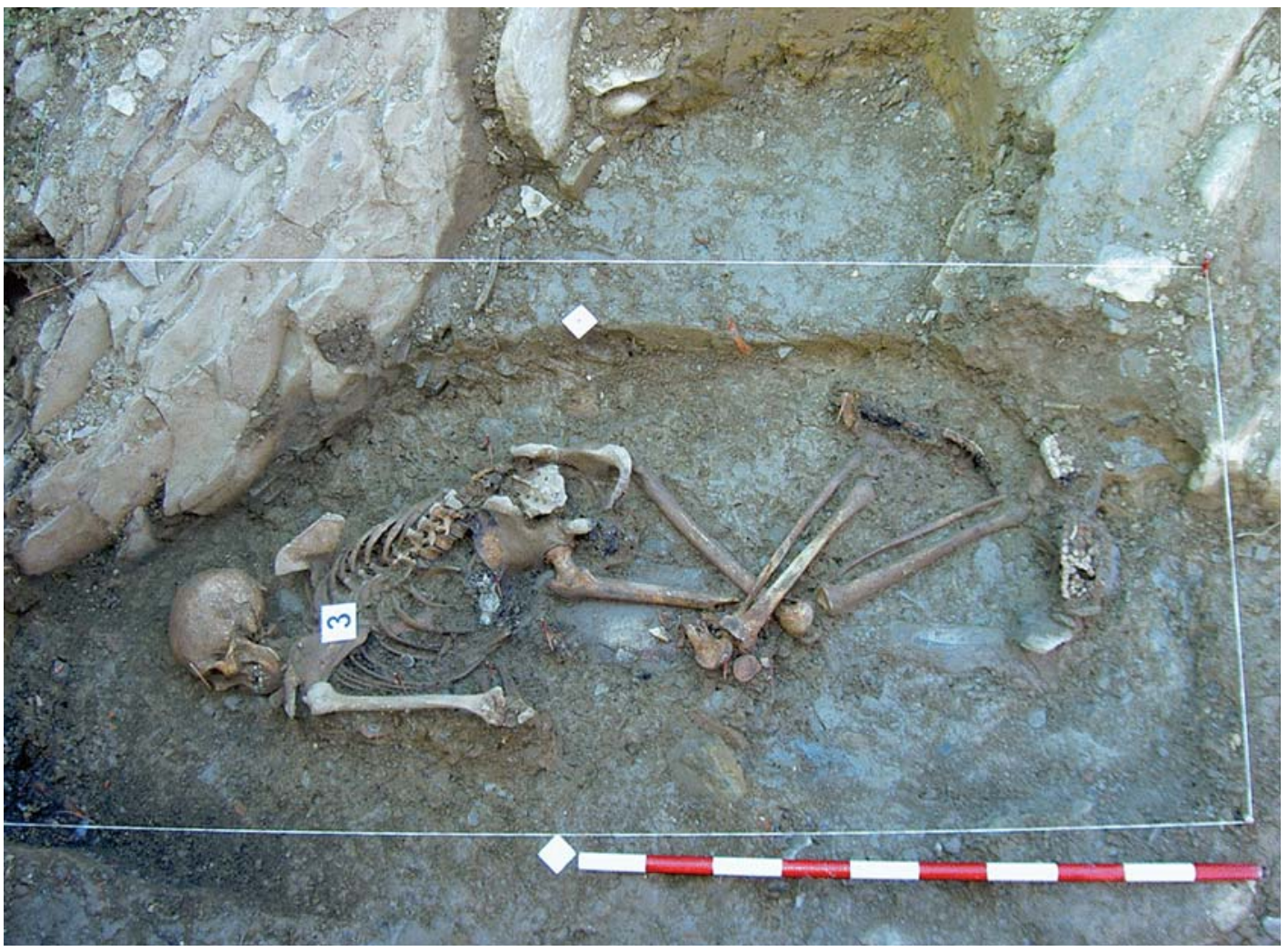

Fig. 14. Fosa

Antzuategi.

Individuo $3 . /$

Antzuategi Grave 1.

Individual 3. 
Reloj de pulsera de correa metálica de $74 \mathrm{~mm}$ de longitud y $16 \mathrm{~mm}$ de ancho. El reloj es cuadrangular de oro. Las agujas marcan las 16:50. Mechero cilíndrico con tapa de rosca. Hebilla con tela adherida de 27 por $31 \mathrm{~mm}$. Trabilla y hebilla de tracción de correas. Cuatro botones de nácar. Siete botones de pasta negros de $25 \mathrm{~mm}$ de diámetro, tipo abrigo. Un botón más de color marrón. Suelas de botas con tachuelas. Fragmento de metralla (Fig. 14).

En la muñeca izquierda del Individuo 3 de Elgeta se descubrió un disco metálico de $26 \mathrm{~mm}$ de diámetro. Se trata en realidad de una moneda de 2 pesetas emitida por el Gobierno vasco en 1937. El Gobierno de Euskadi encargó, a la Real Casa de la Moneda de Bruselas, acuñar 6 millones de piezas de 1 peseta y 2 millones de 2 pesetas. Los diseños de las monedas fueron hechos por Armand Bonnetain y el troquel fue tallado por Alexander Everaerts. Las monedas se entregaron entre los meses de enero y febrero de 1937. Las monedas de 2 pesetas se trasladaron por ferrocarril desde Toulouse y el resto por vía marítima desde el puerto de Amberes ${ }^{6}$.

La moneda de 2 pesetas mide $26 \mathrm{~mm}$ de diámetro y pesa 8 gramos. Anverso: dentro de una orla de perlas se observa el rostro de perfil de una mujer que mira hacia la derecha, ataviada con un gorro frigio, símbolo de la libertad. A su alrededor se lee la leyenda en mayúsculas GOBIERNO DE EUZKADI. Reverso: borde de perlas y en el interior de una corona de laurel se halla escrito 2 PESETAS y debajo 1937 (Fig. 15).

En este caso, en el reverso de la moneda fueron borradas las letras del centro y se grabó el número de gudari 71513 (Fig. 16). A ambos lados de la personalizada placa de identificación se observan dos orificios para colocar unos remaches que la sujetaban a una tira de cuero de la muñequera.

Según los registros de nóminas del Batallón Dragones esta placa de identificación correspondería a J.Z.M., natural de Mondragón. Tenía el sobrenombre de "Noche". Por testimonio de un compañero del mismo batallón, recogido por Juan Ramón Garay de Intxorta Kultur Taldea,
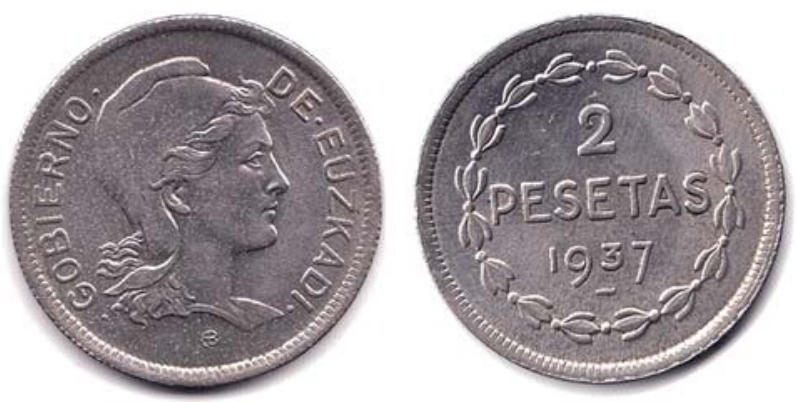

Fig. 15. Anverso y reverso de la moneda de 2 pesetas del Gobierno de Euzkadi (1937). / Obverse and reverse of the 2 peseta coin minted by the Government of Euzkadi (1937)

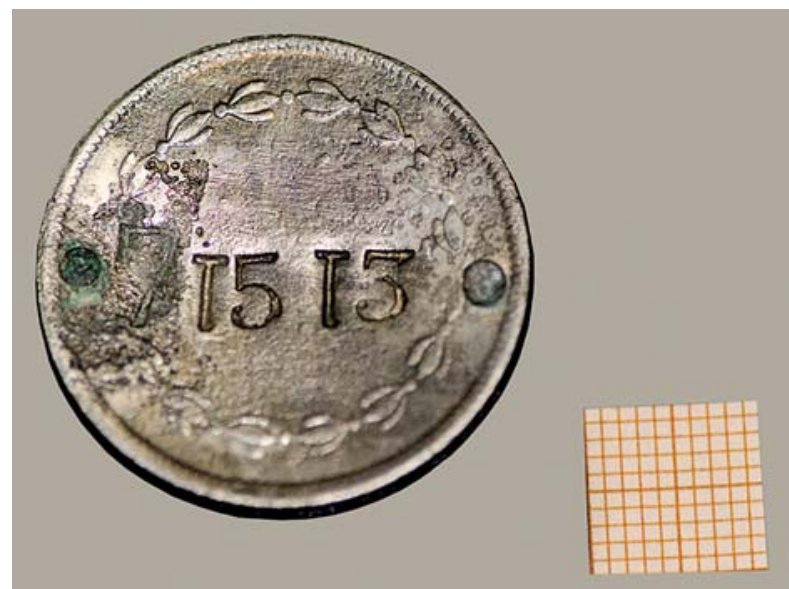

Fig. 16. Placa personalizada número 71513 en moneda de 2 pesetas, correspondiente a J.Z.M. / Personalised dog tag number 71513 made from a 2 peseta coin, belonging to J.Z.M

a "Noche" y a otro llamado "el castellano", por su origen, les encomendaron trasladar un parte a Intxorta. No regresaron de esa misión porque fueron apresados por los soldados franquistas, posiblemente los regulares, que llegaron inicialmente a Elgeta. Entre las nóminas del 15 de abril y el 15 de mayo se detecta la baja de J.Z.M. y de L.B.N., cuyo número de ficha era 71623 , que corresponderían, presumiblemente, a dos de los tres individuos inhumados en la primera fosa de Elgeta.

\section{GANZABAL 01}

El Sr. Alfredo Irusta, del Departamento de Antropología de la S.C. Aranzadi, comunicó la existencia de un enterramiento localizado por Alberto Sampedro en una trinchera en el monte Ganzabal (Fig. 17), término municipal de Amorebieta-Etxano (Bizkaia), en la conocida como Cota 333. En dicho lugar se situó la línea del frente de guerra entre abril y mayo de 1937

A finales del mes de abril de 2008 se procedió a la recuperación de los restos óseos ligeramente disgregados que estaban sepultados de manera superficial junto a un muro de piedra que deslinda las parcelas y que fue aprovechado como parapeto durante los enfrentamientos. De hecho, la inhumación se hallaba en el hueco de la trinchera que había sido excavada junto a dicho muro y que permitía un mejor resguardo para los soldados allí situados.

El individuo se hallaba en posición decúbito supino con las extremidades superiores extendidas y las inferiores ligeramente flexionadas. Esta disposición parece indicar la postura en la que quedo el cuerpo del soldado tras ser abatido en la misma trinchera.

En el área del tórax se recuperó una placa de identificación. Se trata de un disco metálico de $25 \mathrm{~mm}$ de diámetro que tiene dos remaches. En el centro y ocupando la

${ }^{6} \mathrm{http}: / /$ blognumismatico.com/2012/11/23/las-monedas-de-euzkadi-de-1937/ 

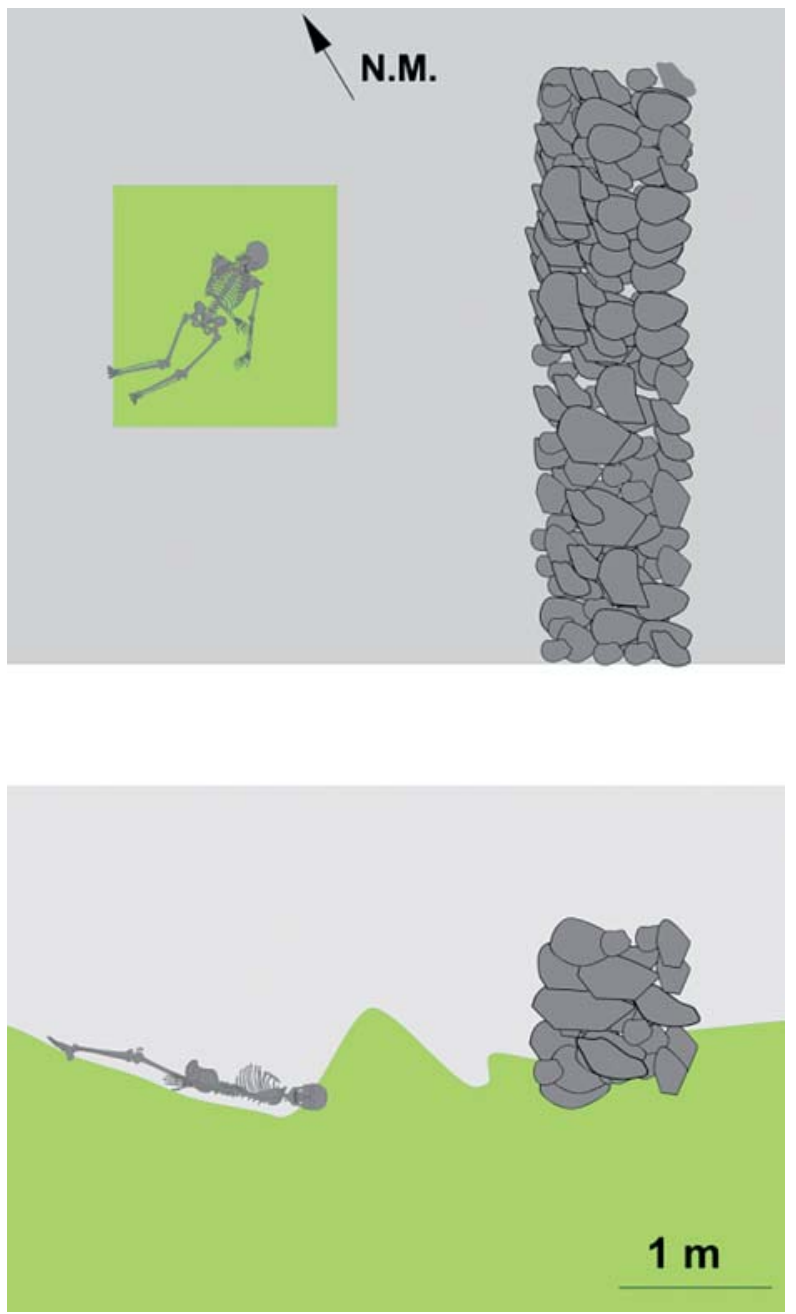

Fig. 17. Disposición del miliciano en la trinchera en Ganzabal (Amorebieta-Etxano, Bizkaia). / Position of the militiaman in the trench at Ganzabal (Amorebieta-Etxano, Biscay).

anchura total del disco se puede leer el número de identificación 71228 (Fig. 18).

Consultados los registros de nóminas de los diversos batallones se consiguió establecer su identidad, que correspondería al miliciano E.B.L., perteneciente al Batallón Dragones.

En el documento conservado en el Archivo Nacional de Euskadi "Registro central de fallecidos en campaña", se recogen los datos de este miliciano, natural de Fuenterrabía, que murió a los 30 años de edad el 9 de mayo de 1937 en Euba. Era tranviario y estaba casado.

\section{GANZABAL 02}

En este caso, el Sr. Joseba Diéguez, otro miembro colaborador de la S.C. Aranzadi, descubrió varios objetos metálicos en el monte Ganzabal. Entre ellos se hallaba una placa de identificación, que no estaba asociada a ningún enterramiento.

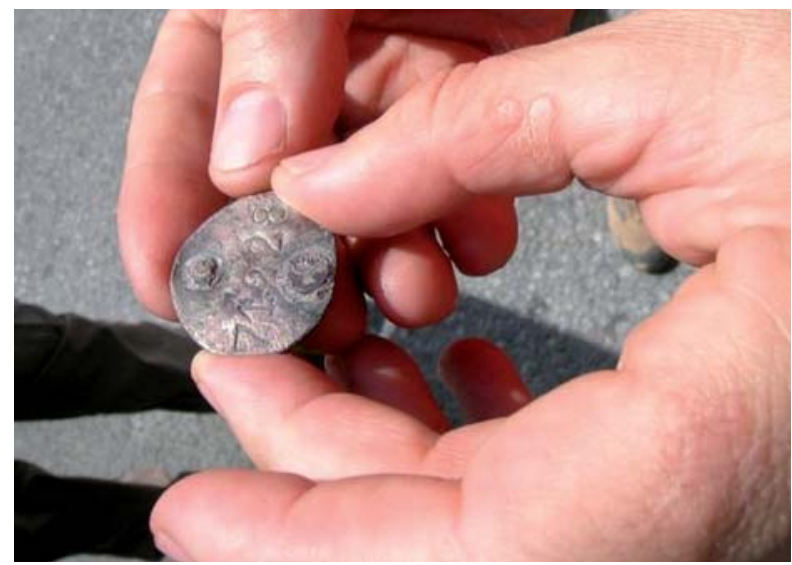

Fig. 18. Placa de identificación hallada junto al miliciano en Ganzabal./ Dog tag found with the militiaman at Ganzabal.

La placa es de tipo ovalada-rectangular. En ambos laterales tiene perforaciones elípticas, para permitir engarzar una cinta de cuero. Se trata, pues, de una placa de muñequera. En el anverso se puede leer sin dificultad y dispuestos en tres líneas: "A N V/ 11104/ BONI-TA" (Fig. 19).

En el listado registrado de pago de nóminas del Batallón de Infantería número 6 , Brigada 13 ( $1^{\circ}$ de ANV), del 31 de mayo de 1937 está inscrito el número de placa de identificación 11104, que correspondería a B.S.M., natural de Barakaldo. Este soldado murió a los 29 años de edad, el 1 de junio de 1937, según consta en la notificación de defunción. Formaba parte del primer batallón reclutado por ANV (Acción Nacionalista Vasca).

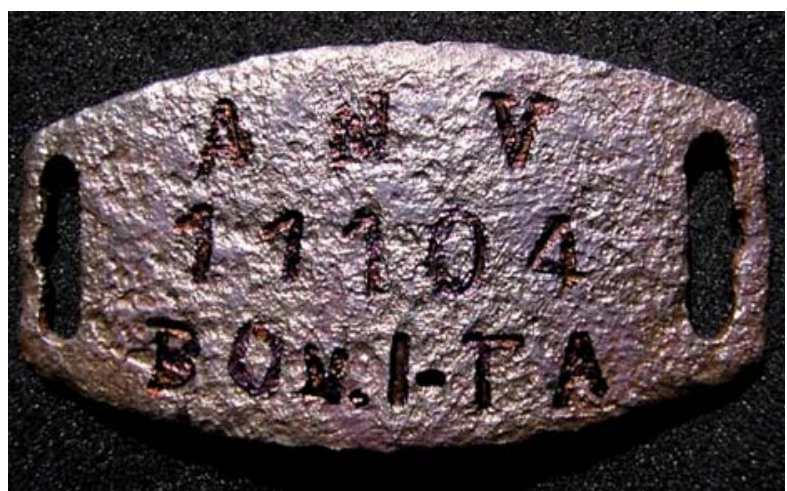

Fig. 19. Placa de identificación personalizada hallada en Ganzabal con los datos de su titular. / Personalised dog tag found at Ganzabal with the information about its owner.

\section{LEMOATZ}

En agosto de 2014 se inicia un proyecto de campos de trabajo, promovido por el Ayuntamiento de Lemona y la Sociedad de Ciencias Aranzadi, para la recuperación y puesta en valor de las líneas de trincheras de Peña Lemona, donde tuvieron lugar importantes enfrentamientos en junio de 1937. Coincidiendo con dichas tareas, en una prospección realizada en la ladera norte, el Sr. Alberto Sampedro localizó un 
objeto metálico a escasa profundidad, que resultó ser una placa de hebilla de cinturón del ejército vasco. Junto a dicha placa se hallaban, asimismo, dos cartucheras. El hallazgo de un fragmento de diáfisis de húmero informaba de que podía tratarse del enterramiento de un combatiente. De hecho, a 30 m más abajo en la ladera en línea recta se habían recuperado con anterioridad los restos de otro soldado.

El 26 de octubre de 2014, un equipo integrado por arqueólogos y antropólogos efectuó las tareas de exhumación y recuperación arqueológica, contando con la colaboración de miembros de la asociación de memoria histórica, Lemoatx1937.

El enterramiento se encontraba en un pequeño rellano, en la base de un pino y delimitado en la parte alta por un murete de piedra.

Más que una fosa, se trata de un enterramiento improvisado, que posiblemente fue realizado por los milicianos de su compañía. El soldado estaba enterrado en posición decúbito supino, con la cabeza apoyada en el lado derecho. El brazo izquierdo flexionado hacia arriba y el derecho semiextendido sobre la cavidad abdominal. Las extremidades inferiores estaban flexionadas hacia su lado derecho, la pierna izquierda dispuesta sobre la derecha. El estado del esqueleto es, en general, deficiente. El área del tronco se hallaba especialmente deteriorado por acción tafonómica de la lluvia y las raíces y no se conservan ni costillas, ni vértebras. Los huesos largos estaban mejor preservados, particularmente los de las extremidades inferiores (Fig. 20).

Desde el punto de vista antropológico, se trata de un individuo masculino de edad adulta joven.

Posiblemente, la muerte de este soldado del ejército vasco se produjo durante los días 3 a 5 de junio de 1937, cuando tuvo lugar el contraataque de las tropas franquistas

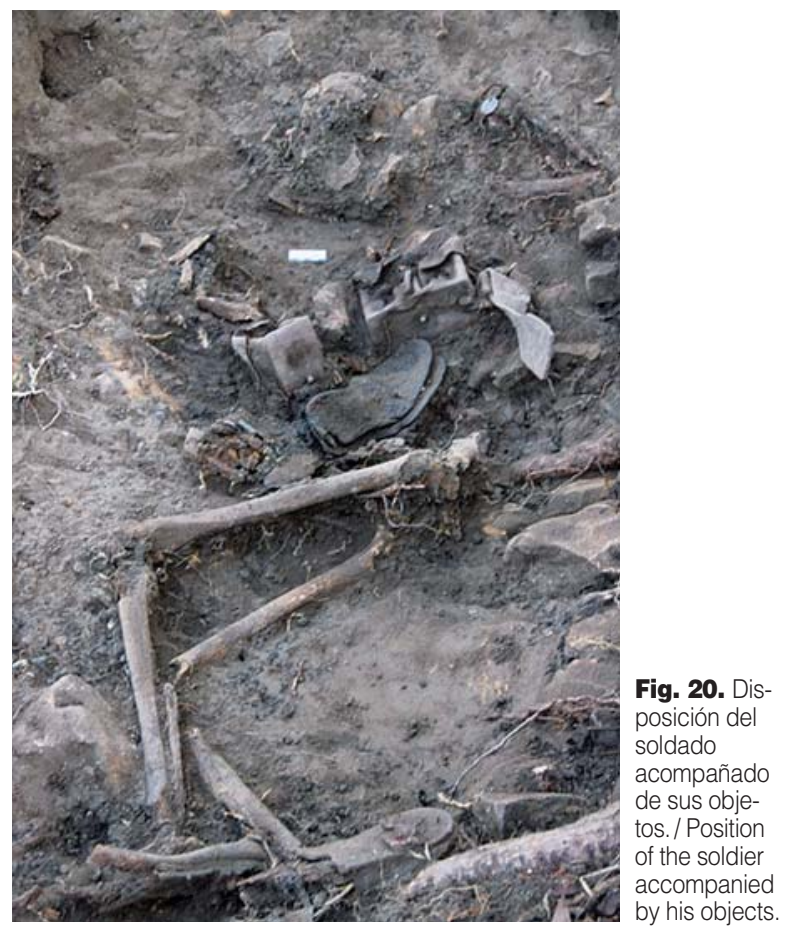

en su avance hacia el cinturón de hierro que protegía la ciudad de Bilbao.

En el momento de su muerte, que se puede atribuir a una explosión por los fragmentos de metralla que se han localizado, llevaba consigo un gran número de objetos que correspondían a los pertrechos característicos de un soldado (Fig. 21).

Así, se ha recuperado el correaje característico de un fusilero con dos cartucheras, acopladas en la parte anterior del cinturón, que conservan en su interior peines de

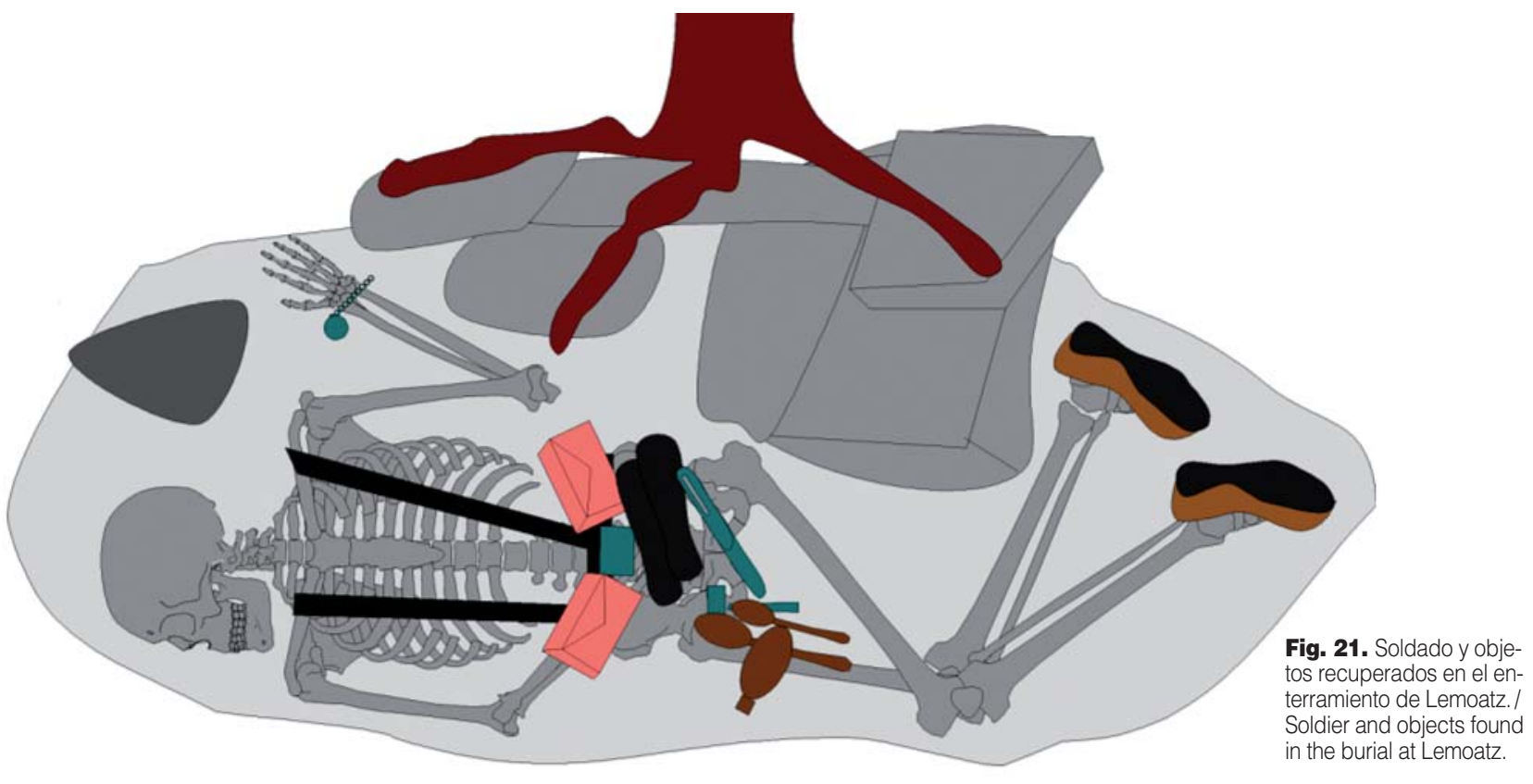


munición de repuesto. Estaban hechas en goma, tipo garay, o de tela vulcanizada que se fabricaba en Bizkaia.

Entre ambas cartucheras se hallaba la hebilla con el escudo del Gobierno Vasco. Este tipo de hebilla fue suministrada a todos los batallones del Ejército de Euzkadi, Eusko Gudarostea, que dependían de la Consejería de Defensa del Gobierno Vasco (Fig. 22). El escudo se realizaba mediante técnica de estampación sobre una lámina fina que luego iba soldada a la hebilla rectangular.

Sobre la cavidad abdominal se concentraban un número de objetos que pudieron estar guardados en una bolsa de tela o en un zurrón. Se trata de unas suelas de caucho de alpargata, una pluma estilográfica, dos maquinillas de afeitar de cuchilla completas, además de dos cucharas de latón y una granada de mano. En los pies conservaba el calzado de cuero.

Sin embargo, el objeto más significativo consiste en la pulsera de cadena de eslabones que presentaba en la muñeca izquierda. De dicha pulsera pende un disco metálico que tiene grabado el número 72865 (Fig. 23).

Tras consultar en el Archivo Nacional de Euskadi de Bilbao la relación de nóminas de los diferentes batallones que constituyeron el Eusko Gudarostea, donde se recogen los números de placas de identificación vinculados a los soldados a los que se habían asignados, se pudo descubrir que el número 72865 corresponde a H.B.R., natural de Barakaldo y miliciano del Batallón 28 de dicha ciudad.

\section{CONCLUSIONES}

- Las placas de identificación han cumplido la función para la que fueron diseñadas, identificar al soldado al que se asocian. Ese cometido se formalizó en el periodo coetáneo, en el que el cadáver fue trasladado e inhumado; pero, también, se ha logrado en las exhumaciones de soldados en la actualidad.

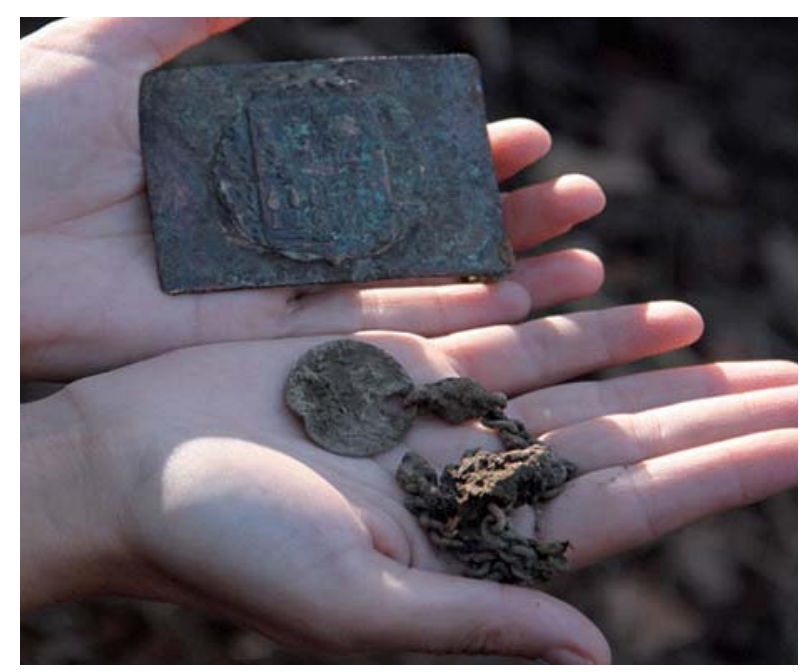

Fig. 22. Placa de hebilla de cinturón y pulsera con el disco en el momento de la exhumación. / Belt buckle plate and bracelet with the disc when it was exhumed.

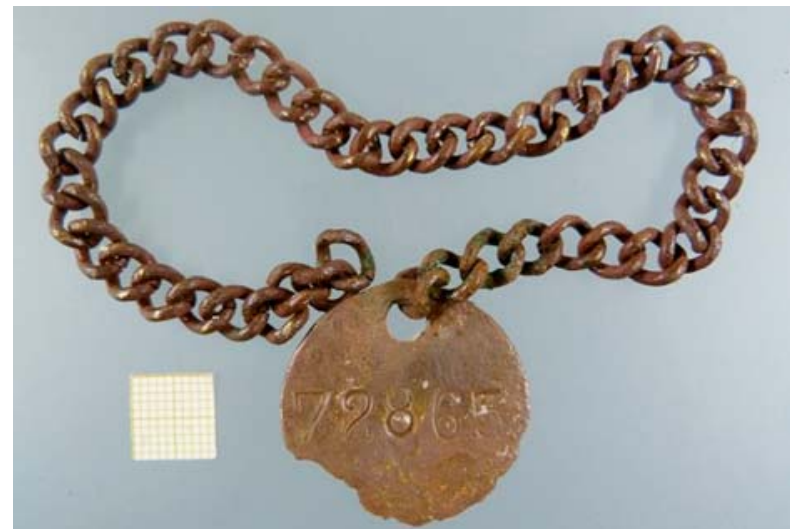

Fig. 23a. Pulsera de eslabones del que pende el disco de identificación $n^{\circ} 72865$. / Chain bracelet holding the dog tag number 72865

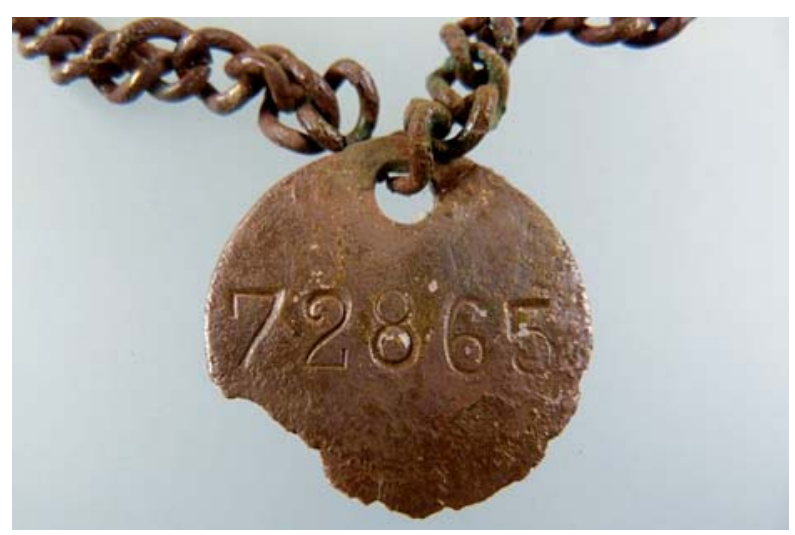

Fig. 23b. Número 72865. / Number 72865

- Su validez justifica el uso generalizado a nivel mundial.

- La exhumación de enterramientos de combatientes realizada con métodos arqueológicos posibilita un control más exhaustivo de los restos y los objetos asociados.

- La importancia de los objetos asociados en la arqueología queda patente en este tipo de objetos con un fuerte carácter personal e individualizante. A través de los objetos podemos conocer la indumentaria que vestía, los pertrechos o los hábitos de higiene, así como la identidad de su propietario y aspectos de su biografía.

- Ha quedado patente la necesaria colaboración entre los prospectores, que recuperan objetos como proyectiles, insignias u otros en espacios donde tuvieron lugar los enfrentamientos, con los arqueólogos. Gracias a esa cooperación se han podido documentar varios enterramientos de soldados en el País Vasco.

\section{AGRADECIMIENTOS}

En este trabajo han colaborado: Cristina Martín, José Ángel Etxaniz, Juan Ramón Garay, Iban Gorriti, Diego Leonet, David Ramírez, José Sancho y Juan $\mathrm{M}^{a}$ Txoperena. Asimismo agradecemos la participación de la Fundación Sabino Arana y de la Asociación de Amigos de Laguardia. 


\section{HALLAZGOS AISLADOS}

Asimismo, se han producido otros hallazgos fortuitos en labores de prospección en escenarios bélicos:

\section{Placa número 78539}

Hallada en 2006 en el monte Mirugain (Araba) por delante de la trinchera a 698 m s.n.m. en las coordenadas $X$ 530203 Y 4763062 (Fig. 24).

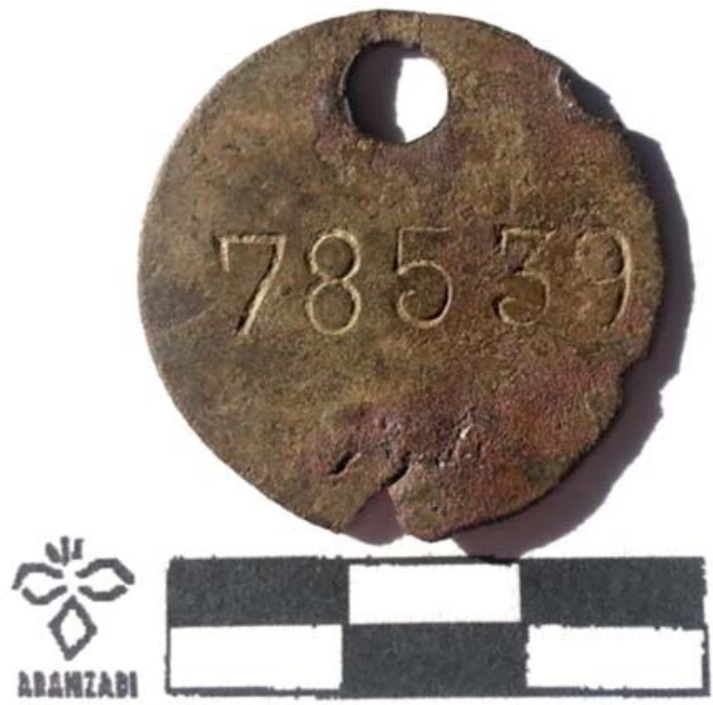

Fig. 24. Placa número 78539. (Alberto J. Sampedro). / Dog tag number 78539. (Alberto J. Sampedro).

\section{Placa número 84481}

Hallada en el monte monte Arrietabaso de Urkiola (Bizkaia) a 1.011 m s.n.m.

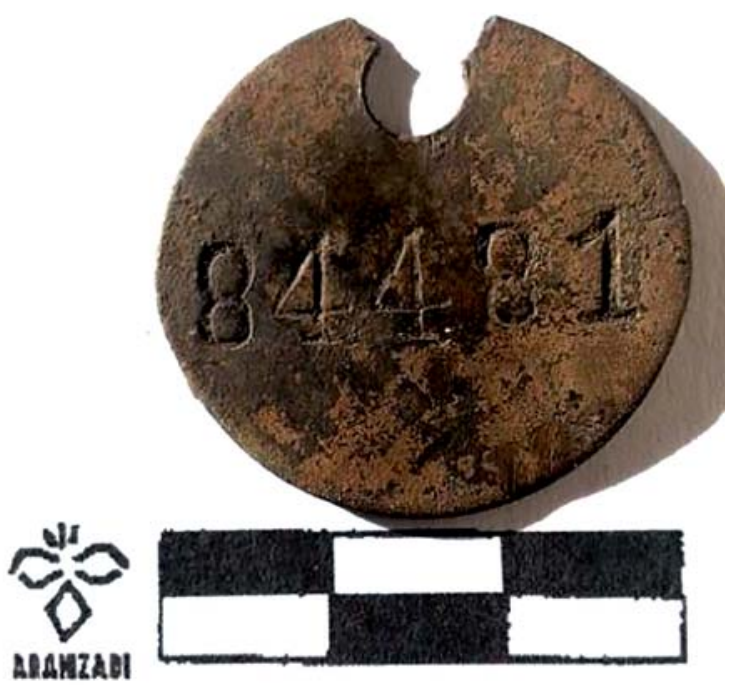

Fig. 26. Placa número 84481. (Alberto Sardón). / Dog tag number 84481. (Alberto Sardón).

\section{Placa número XX46 o XX16}

Encontrada en 2009 el monte Astaiz (Araba) a 904 m s.n.m. en las coordenadas X 512575, Y 4762000. Es una chapa de aluminio de un bar o café de Bilbao. Tiene la inscripción La Terraza 205 Bilbao. Por la parte trasera se grabó un número que es ilegible, tan solo se lee XX46 o XX16. Se encontró junto con una insignia de Milicias Socialistas.

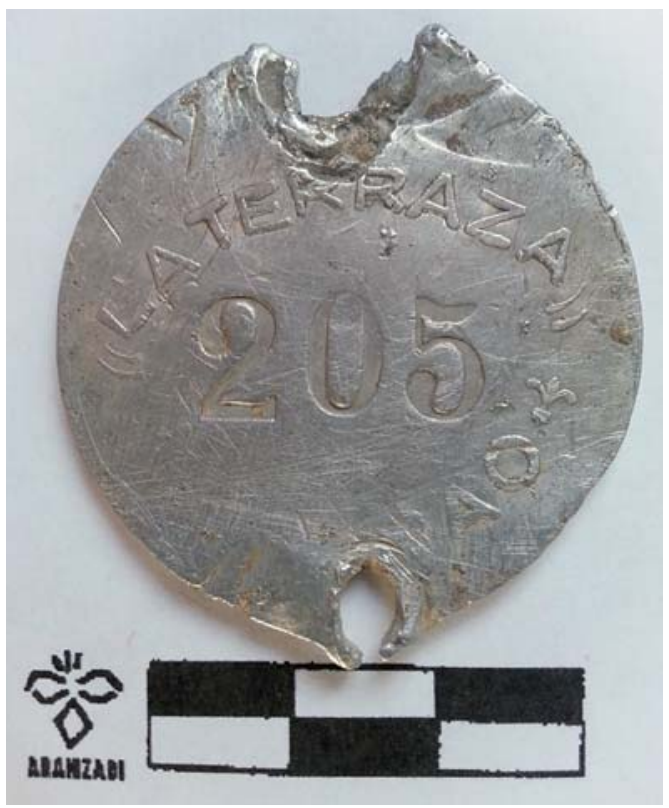

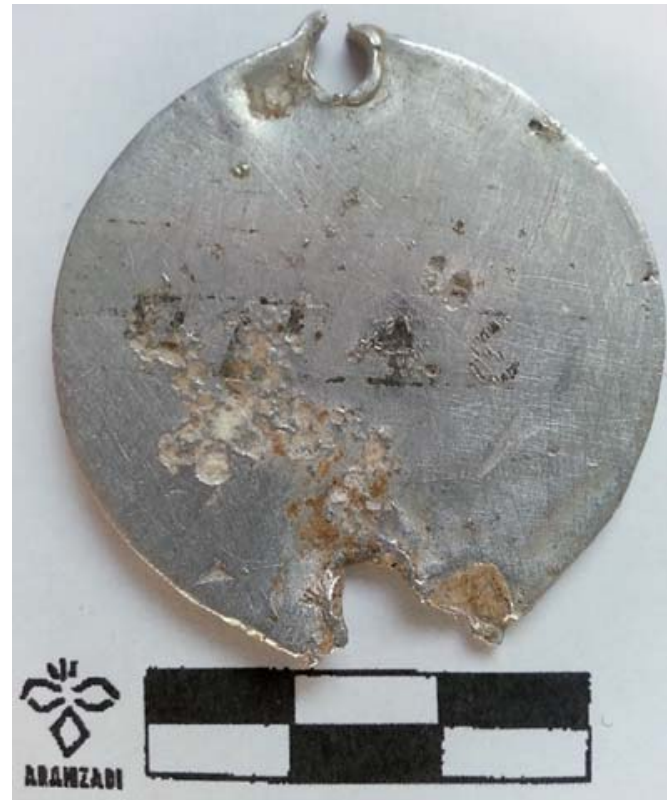

Fig. 25. Placa número XX46 o XX16. (Alberto J. Sampedro)./ Dog tag number XX46 or XX16. (Alberto J. Sampedro) 


\section{Placa número 49425}

Se descubrió en el hayedo de la cara norte del monte Sabigain (Bizkaia) a 954 m s.n.m. Coordenadas: X 527917, Y 4772180.

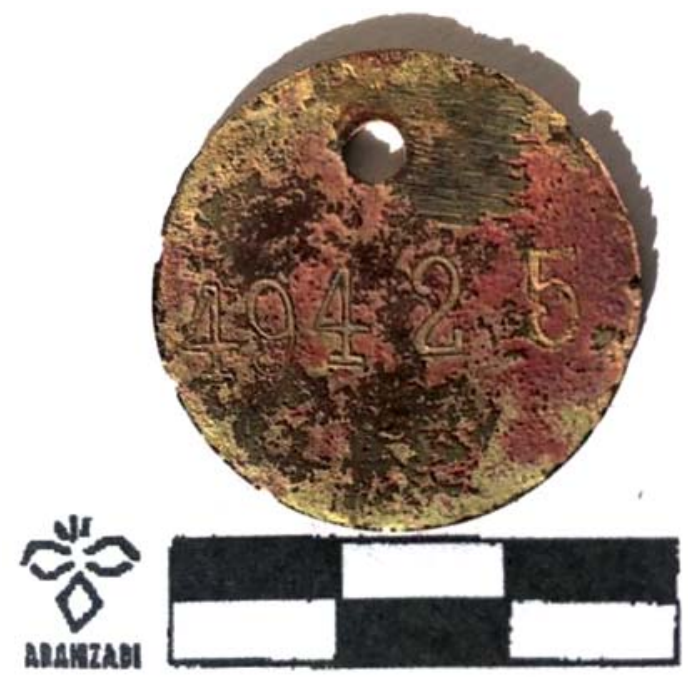

Fig. 27. Placa número 49425. (Alberto Sardón)./ Dog tag number 49425. (Alberto Sardón).

\section{Placa número 13312}

Hallada en el monte Albertia (Araba) a 867 m s.n.m. Coordenadas: X 531480, Y 4759284.

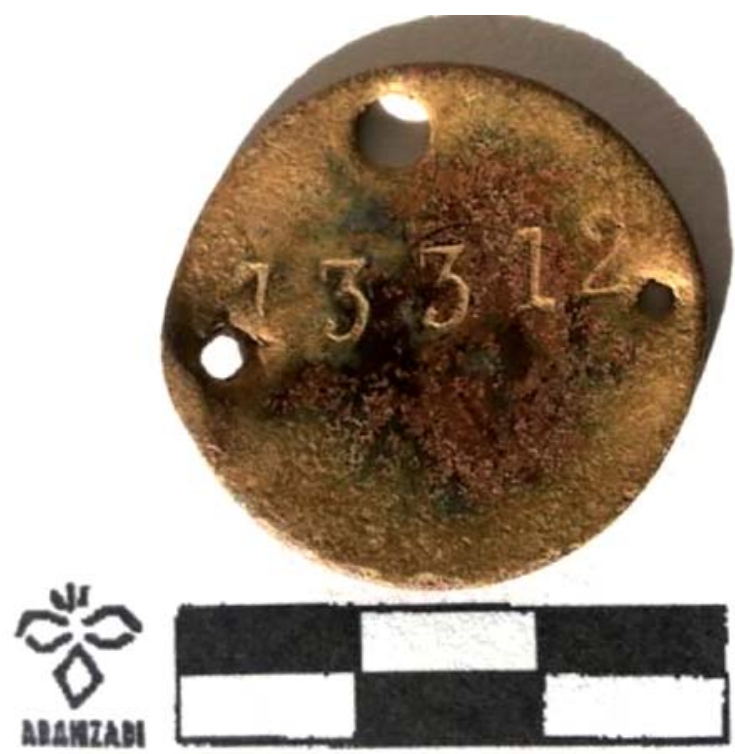

Fig. 28. Placa número 13312. (Alberto Sardón). / Dog tag number 13312. (Alberto Sardón).

\section{Placa número 46164}

Localizada en un refugio en la Posición Avanzada ubicada en la zona conocida como La Susera en el monte San Pedro de Urkabustaiz (Araba), a 711 m s.n.m. Coordenadas: X 502368, Y 4761065.

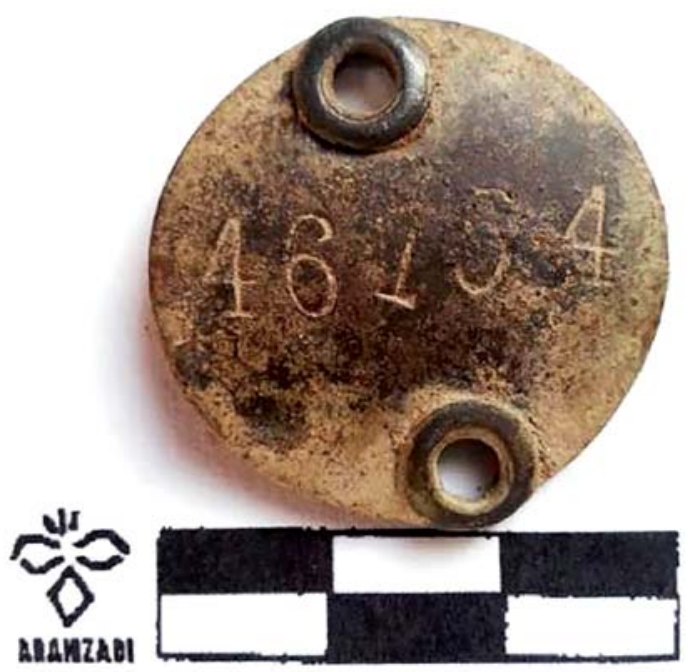

Fig. 29. Placa número 46164. (Alberto Sardón). / Dog tag number 46164. (Alberto Sardón).

\section{Placa número 28078}

Localizada en el monte Eskubaratz (Bizkaia) 1.003 m s.n.m. Coordenadas de la cumbre: X 525986, Y 4774968.

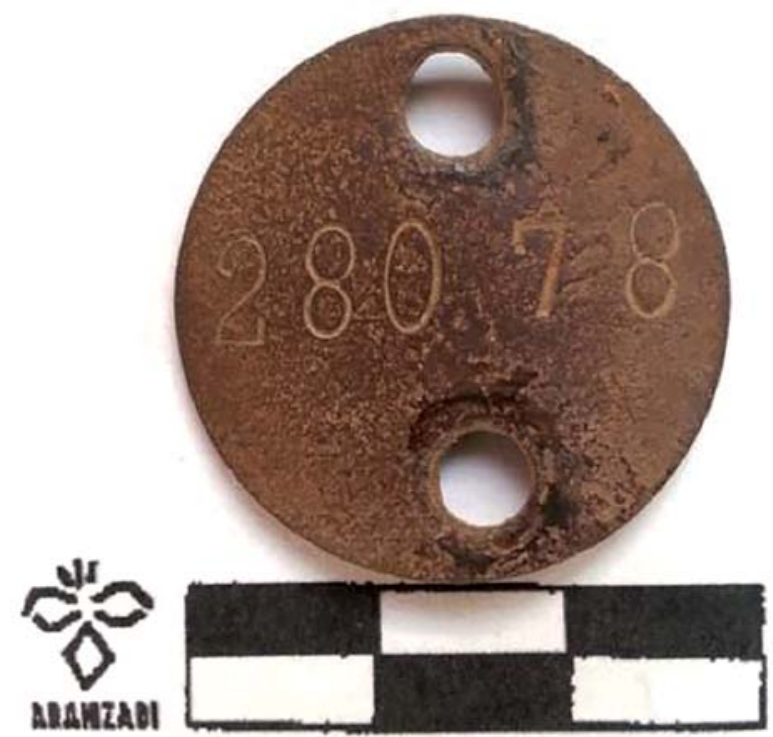

Fig. 30. Placa número 28078. (Eduardo Sardón). / Dog tag number 28078. (Eduardo Sardón). 


\section{Placa número 29294}

Se descubrió en Siskiñe, en el sector de Ubidea.

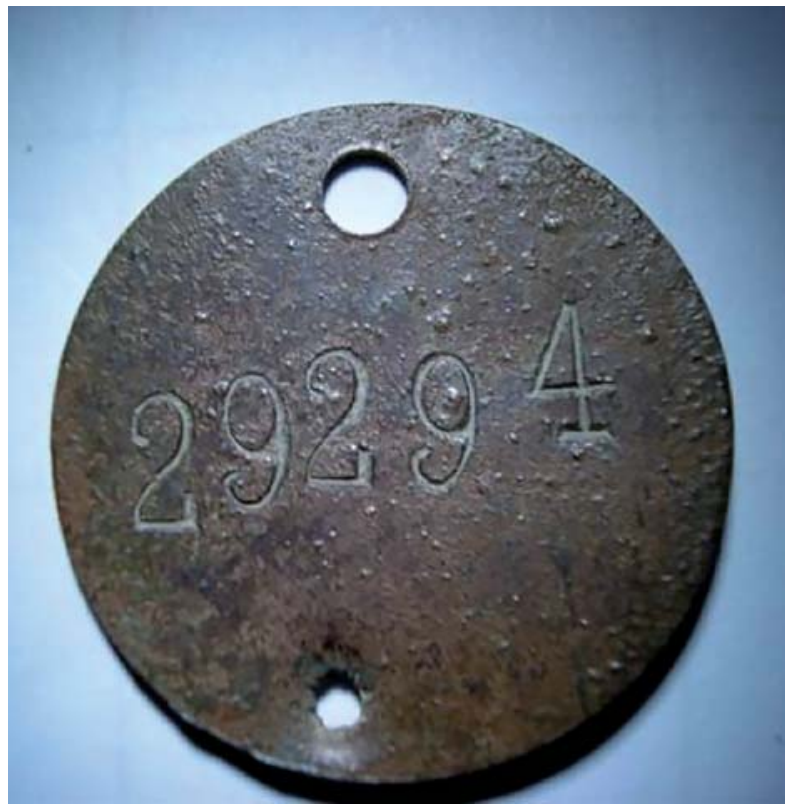

Fig. 31. Placa número 29294. (Joseba Diéguez). / Dog tag number 29294 (Joseba Diéguez).

\section{Placa número 1080336}

Descubierta en el monte San -Bernabé, en el frente de Villarreal.

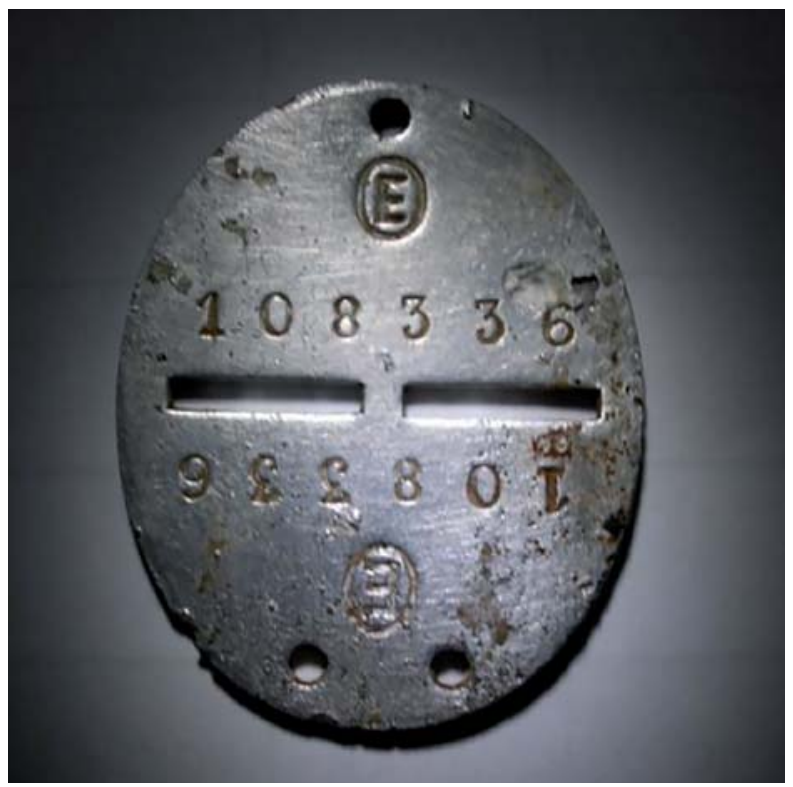

Fig. 32. Placa número 1080336. (Joseba Diéguez). / Dog tag number 1080336. (Joseba Diéguez)

\section{Placa número 1165}

Fue localizada también en el monte Albertia.

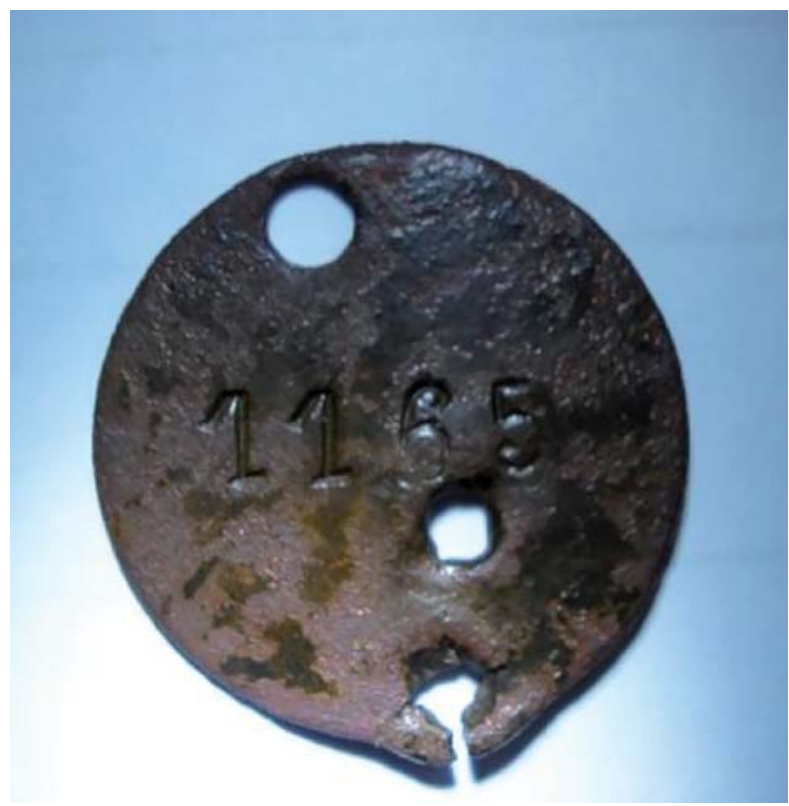

Fig. 33. Placa número 1165. (Joseba Diéguez). / Dog tag number 1165. (Joseba Diéguez).

\section{Placa número 63377}

Se encontró en el monte Betaio.

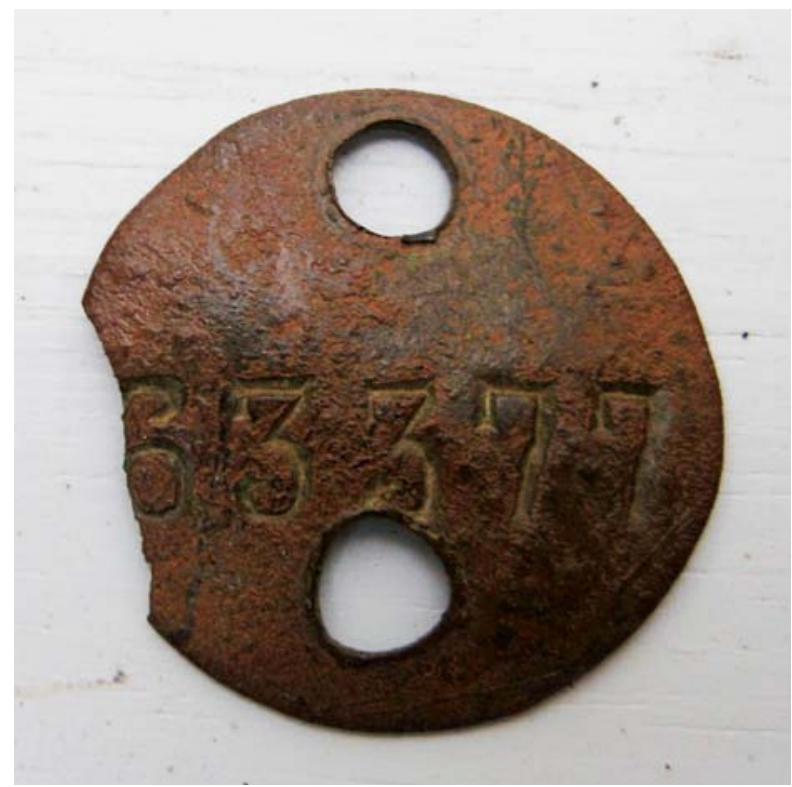

Fig. 34. Placa número 63377. (Alfredo Irusta)/ Dog tag number 63377. (Alfredo Irusta). 


\section{Placa número 35730}

Se encontró en el monte Kolitza. Mide 25 mm de diámetro.

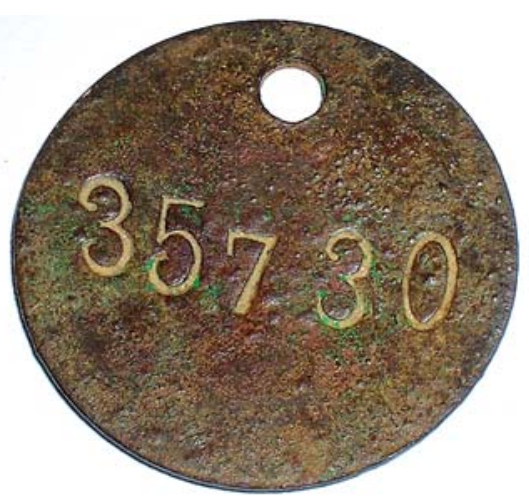

Fig. 35. Placa número 63377. (David Ramírez)/ Dog tag number 35730 (David Ramírez)

\section{Placa número 30492}

Hallada en el monte Jarindo.

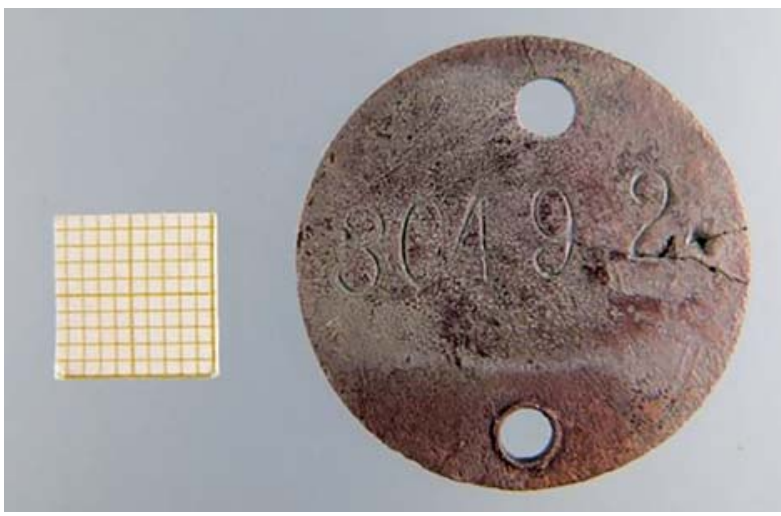

Fig. 36. Placa número 30492. (Jon Etxezarraga). / Dog tag number 30492. (Jon Etxezarraga).

\section{Placa número 37517}

Se localizó en el monte Kalamendi. Se trata de una pulsera metálica con una placa rectangular de $35 \mathrm{~mm}$ de longitud y 15 de anchura. En una de las caras se lee el número 37517; en la otra "L. Uriarte".

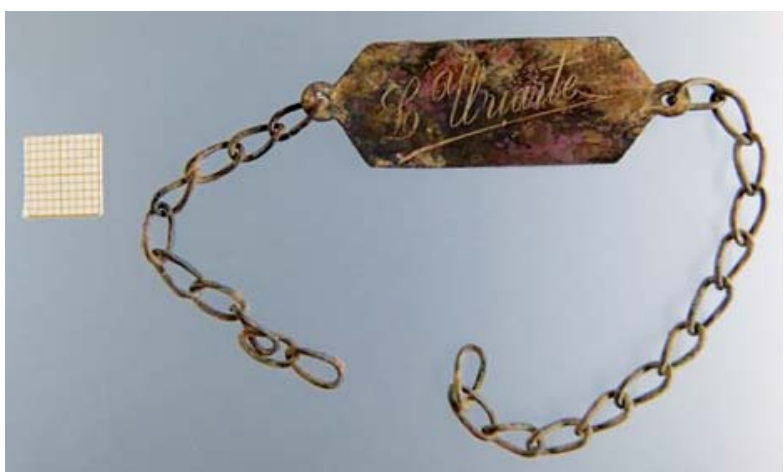

Fig. 37. Placa número 37517. (Jon Etxezarraga)./ Dog tag number 37517 (Jon Etxezarraga).

\section{Placa número 65630}

Se encontró en la Mina Santa Lucía en el monte Udalaitz.

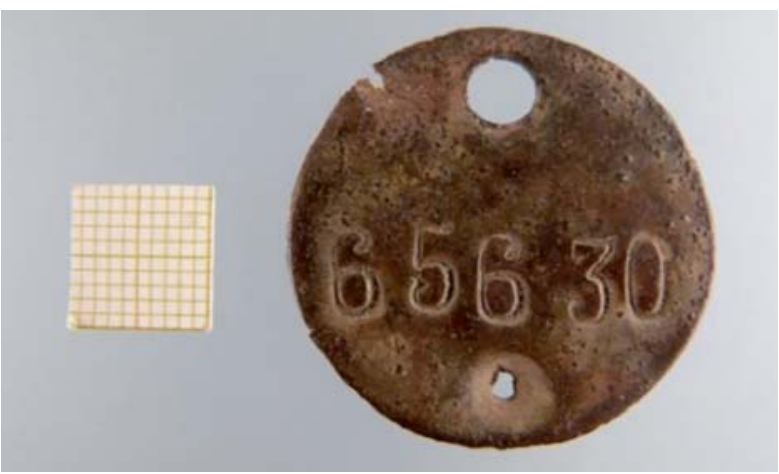

Fig. 38. Placa número 65630. (Jon Etxezarraga). / Dog tag number 65630 (Jon Etxezarraga)

\section{Placa número 39349}

Se halló en el monte Berretín.

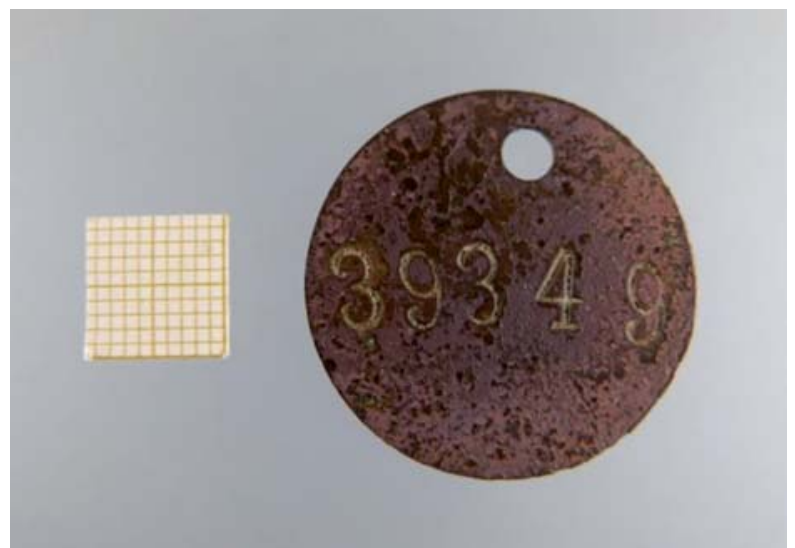

Fig. 39. Placa número 39349. (Jon Etxezarraga). / Dog tag number 39349. (Jon Etxezarraga)

\section{Placa número 78505}

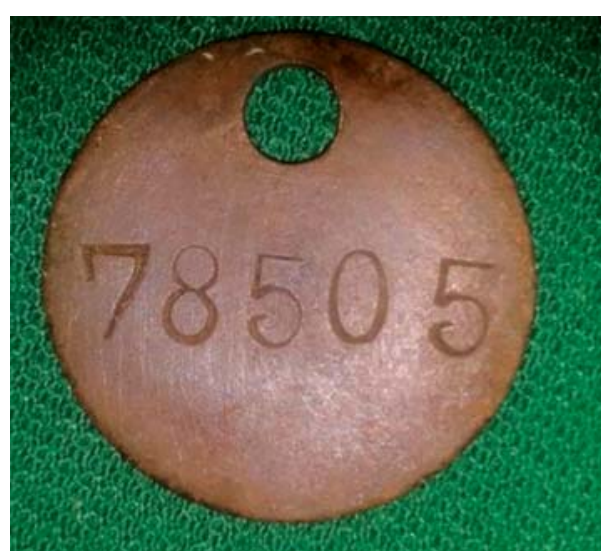

Fig. 40. Placa número 78505.1 Dog tag number 78505. (Xabier Llaguno). 


\section{Placa número 107903}

Se localizó en el área del Frente de Villarreal. Se trata de una placa del ejército (ya referenciada en el texto).

\section{Placa número 77882}

Se halló en el Monte Betaio.

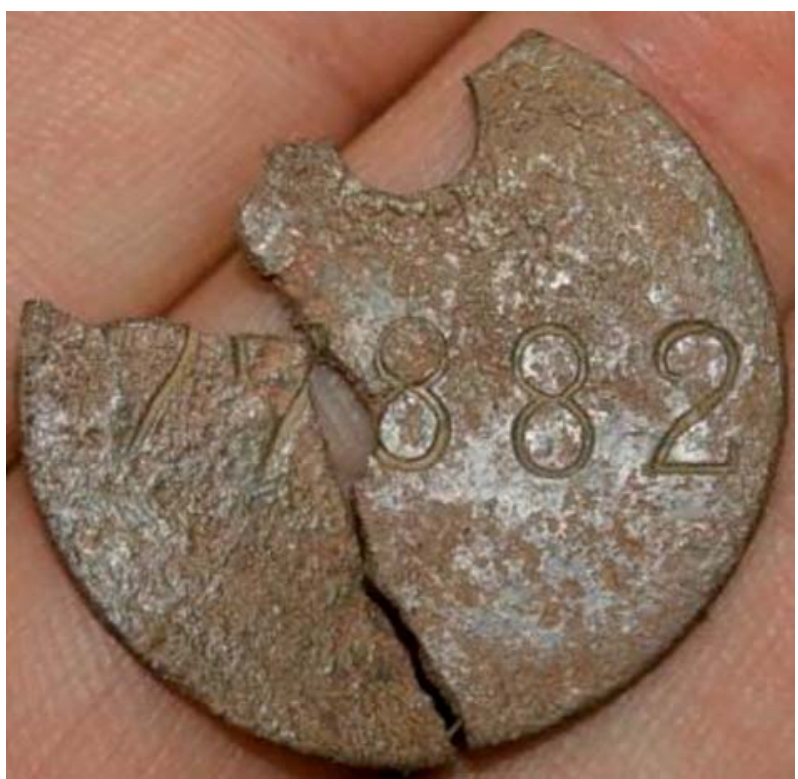

Fig. 41. Placa número 77882. (Ángel Sánchez)/ Dog tag number 77882 (Ángel Sánchez)

\section{Placa número 13295}

Se desconoce el lugar donde apareció.

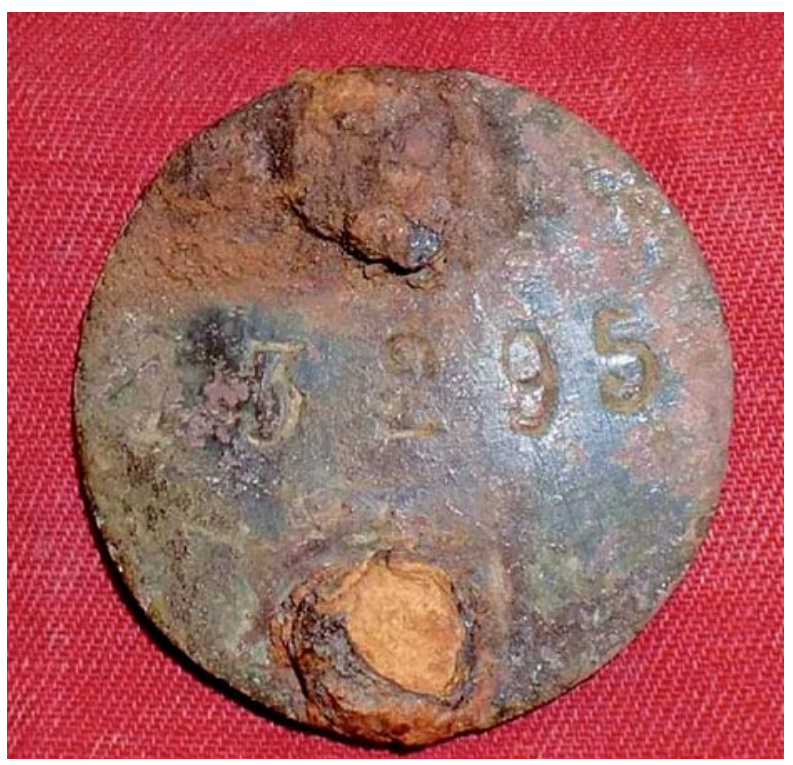

Fig. 42. Placa número 13295. (Ángel Sánchez)/ Dog tag number 13295. (Ángel Sánchez)

\section{Placa número 44284}

Placa identificativa que perteneció a José $\mathrm{M}^{\mathrm{a}} \mathrm{An}$ donegui Berasaluce.

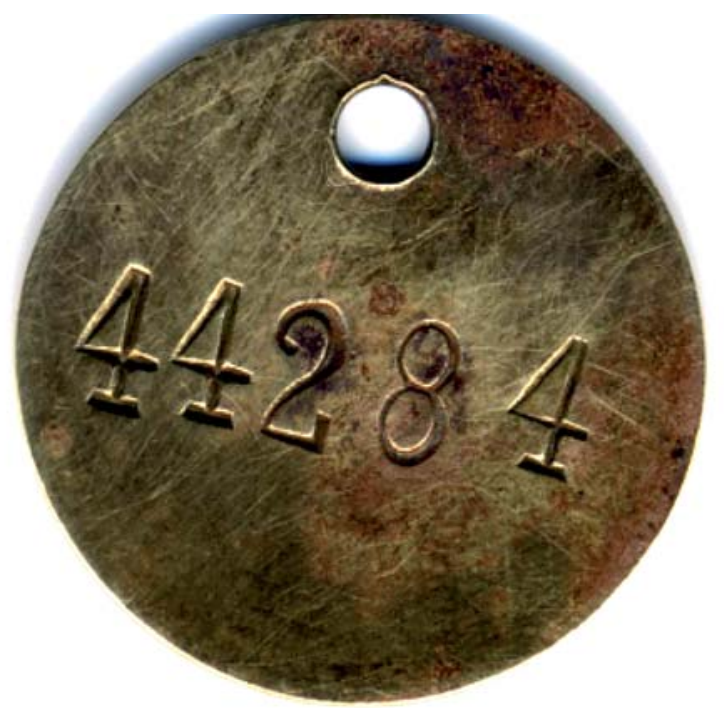

Fig. 43. Placa en posesión de la Familia Andonegi. / Dog tag in the possession of the Andonegi family.

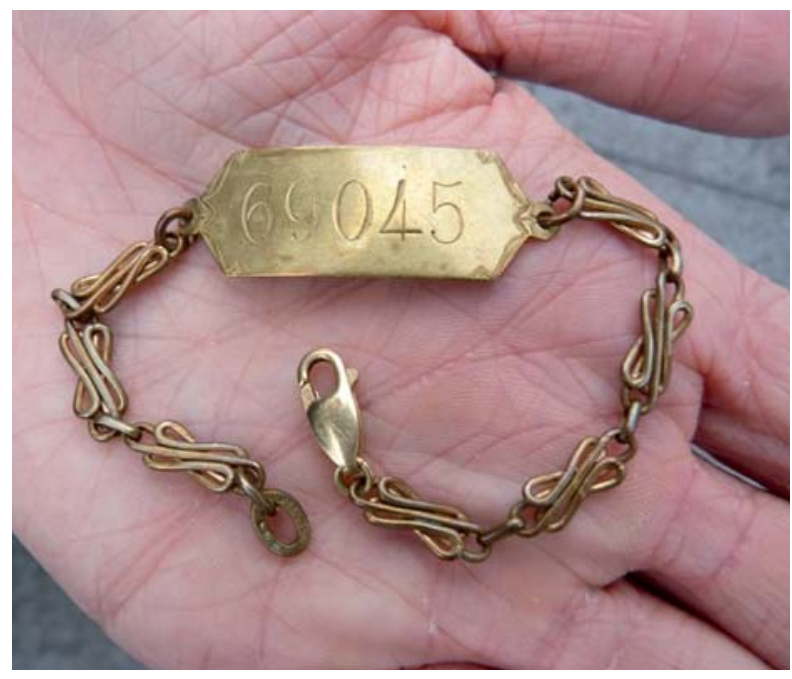

Fig. 44. Placa en pulsera número 69045. Perteneció a José Amozarrain. Dog tag number 6904 belonging to José Amozarrain.

\section{BIBLIOGRAFÍA}

ARTECHE, J.

1970 El abrazo de los muertos. Ed. Icharopena. Zarautz. 301 pp.

CAPDEVILA, L. y VOLDMAN, D.

2002 Du numéro matricule au code génétique:la manipulation du corps des tués de la guerre en quête d'identité. En: Revue International de la Croix-Rouge. Vol. 84. № 848, pp. 751-765. Ginebra 


\section{ETXEBERRIA, F.}

2014 Fosas de carne y hueso. En: Goazen gudari danok. En defensa de la libertad. Elgoibarko Udala y Fundación Sabino Arana. 77-81 pp.

\section{GONZÁLEZ-RUIBAL, A}

2012 Arqueología de la batalla olvidada. Informe de las Excavaciones en los restos de la Guerra Civil en Abánades (Guadalajara). Campaña 2012. CSIC. http://digital. csic.es/bitstream/10261/81034/1/Informe\%20Ab \%C3\%A1nades\%202012.pdf

\section{HERRASTI, L. y ETXEBERRIA, F.}

2014 El cementerio de las botellas: las botellas. En: El Fuerte de San Cristóbal en la memoria: de prisión a sanatorio penitenciario. El cementerio de las botellas. $153-187$ pp. Ed. Pamiela. Pamplona.

\section{LANDOLT, M}

2012 "Archéologíe de la Grande Guerre. La galerie allemande de Kilianstollen à Carspach". https://www.academia.edu/2601820/Fouilles_arch\%C3\%A9ologiques_l e_Kilianstollen_\%C3\%AO_Carspach_Haut-Rhin_

MAIER, L.B. y STAHL, J.W.

2008 Identification Discs of Union Soldiers in the Civil War. Mcfarlandd \& Co Inc. Edition. 212 pp.

\section{OLSEN, B.}

2010 In defense of things: Archaeology and the Ontology of Objects (Archaeology in Society). Altamira Press. 201 pp.

\section{SÁNCHEZ SETIÉN, A.}

2012 Chapas de identificación de la Guerra Civil Española. Uniformes y equipos. http://www.ejercitodelturia.com/chapas-de-identificacion-en-la-guerra-civil-espanola/

SUMMERS, J. (compilador).

2013 Remembering Fromelles. A new cemetery for a new century. 2010. CWGC Publishing.

\section{TRIGUEROS PEÑALVER, F.}

La placa militar de identidad. http://www. portalcultura.mde.es/Galerias/revistas/ficheros/RET_237.pdf

VARGAS ALONSO, F.M.

2001 El Partido Nacionalista Vasco en Guerra: Euzko Gudarostea (1936-1937). Vasconia 31, 305-343. 